IZA DP No. 5151

International Trade and its Effects on

Economic Growth in China

Peng Sun

Almas Heshmati

August 2010

Forschungsinstitut zur Zukunft der Arbeit Institute for the Study of Labor 


\title{
International Trade and its Effects on Economic Growth in China
}

\author{
Peng Sun \\ Liaoning Entry-Exit Inspection and Quarantine Bureau (LNCIQ)
}

Almas Heshmati

Korea University

and IZA

\section{Discussion Paper No. 5151 \\ August 2010}

\author{
IZA \\ P.O. Box 7240 \\ 53072 Bonn \\ Germany \\ Phone: +49-228-3894-0 \\ Fax: +49-228-3894-180 \\ E-mail: iza@iza.org
}

\begin{abstract}
Any opinions expressed here are those of the author(s) and not those of IZA. Research published in this series may include views on policy, but the institute itself takes no institutional policy positions.

The Institute for the Study of Labor (IZA) in Bonn is a local and virtual international research center and a place of communication between science, politics and business. IZA is an independent nonprofit organization supported by Deutsche Post Foundation. The center is associated with the University of Bonn and offers a stimulating research environment through its international network, workshops and conferences, data service, project support, research visits and doctoral program. IZA engages in (i) original and internationally competitive research in all fields of labor economics, (ii) development of policy concepts, and (iii) dissemination of research results and concepts to the interested public.
\end{abstract}

IZA Discussion Papers often represent preliminary work and are circulated to encourage discussion. Citation of such a paper should account for its provisional character. A revised version may be available directly from the author. 


\section{ABSTRACT}

\section{International Trade and its Effects on Economic Growth in China}

International trade, as a major factor of openness, has made an increasingly significant contribution to economic growth. Chinese international trade has experienced rapid expansion together with its dramatic economic growth which has made the country to target the world as its market. This research discusses the role of international trade in China's economic growth. It starts with a review of conceptions as well as the evolution of China's international trade regime and the policy that China has taken in favor of trade sectors. In addition, China's international trade performance is analyzed extensively. This research then evaluates the effects of international trade on China's economic growth through examining improvement in productivity. Both econometric and non-parametric approaches are applied based on a 6-year balanced panel data of 31 provinces of China from 2002 to 2007 . For the econometric approach, a stochastic frontier production function is estimated and province specific determinants of inefficiency in trade identified. For the non-parametric approach, the Divisia index of each province/region is calculated to be used as the benchmark. The study demonstrates that increasing participation in the global trade helps China reap the static and dynamic benefits, stimulating rapid national economic growth. Both international trade volume and trade structure towards high-tech exports result in positive effects on China's regional productivity. The eastern region of China has been developing most rapidly while the central and western provinces have been lagging behind in terms of both economic growth and participation in international trade. Policy implications are drawn from the empirical results accordingly.

JEL Classification: $\quad$ C23, D24, F10, O24, R58

Keywords: international trade, economic growth, China, panel data, stochastic frontier

Corresponding author:

Almas Heshmati

Department of Food and Resource Economics

College of Life Sciences and Biotechnology

Korea University

East Building, Room 217

Anam-dong Seongbuk-gu

Seoul, 136-701

Korea

E-mail: heshmati@korea.ac.kr 


\section{Introduction}

China's international trade has experienced rapid expansion together with its dramatic economic growth which has made the country target the world as its market. The stable political system, vast natural resources and abundant skilled labor in China have made it a modern global factory. Discussions of the role that international trade plays in promoting economic growth and productivity in particular, have been ongoing since several decades ago. A core finding from the comprehensive literature shows that internationally active countries tend to be more productive than countries which only produce for the domestic market. Due to liberalization and globalization, a country's economy has become much more closely associated with external factors such as openness. Thus, conducting a study on the effects of international trade on economic growth is of great significance in this globalized era. It helps policymakers map out appropriate policies by determining the source of productivity growth with respect to international trade.

Since the initiation of economic reforms and the adoption of the open door policy, international trade and China's economy have experienced dramatic growth. China's integration into the global economy has largely contributed to its sustained economic growth. Some of the industries with comparative advantages began to acquire a high level of specialization, and China has achieved a high growth rate of GDP, as well as an enormous inflow of hard currency and increase in employment. Additionally, China's participation in international trade has also contributed to improvement in productivity of domestic industries and advancement of technology. On one hand, large imports of machinery goods in the early 1990s had an immediate impact on productivity through the application of technology embodied in them. On the other hand, the level of science and technology in China increased dramatically due to the effect of "learning by doing." Therefore, research on how international trade contributed to China's economic growth can serve as a distinguishing case study demonstrating how a latecomer catches up with forerunners by increasing its participation on the global stage.

This research starts with literature review from the perspective of international trade effect on economic growth in part 2. In part 3, the theoretical model and estimation procedures of this research are discussed respectively. Both econometric and non-parametric approaches are applied in this research. The data and variables used in this research are explained in part 4 . The characteristics of a 6-year balanced panel data of 31 provinces/regions of China from 2002 to 2007 are discussed, followed by the analysis of each variable in the model. Part 5 presents empirical results according to the model constructed in this research by offering an in-depth explanation of each coefficient and comparison with the previous pieces of research. In part 6 and 7, policy implications and the main conclusion are drawn respectively. 


\section{Literature Review}

Empirically, there appears to be good evidence that international trade affects economic growth positively by facilitating capital accumulation, industrial structure upgrading, technological progress and institutional advancement. Specifically, increased imports of capital and intermediate products, which are not available in the domestic market, may result in the rise in productivity of manufacturing (Lee, 1995). More active participation in the international market by promoting exports leads to more intense competition and improvement in terms of productivity (Wagner, 2007). Learning-by-doing may be more rapid in export industry thanks to the knowledge and technology spillover effects. In addition, the benefits of international trade are mainly generated from the external environment, appropriate trade strategy and structure of trade patterns. There are comprehensive empirical studies on the impact of trade on economic growth. Before the 1960s, research on trade effects was limited to a few specific countries. With the development of econometrics, however, many complicated methods based on a mathematical model were introduced to analyze the interactive impact between trade and economic growth. So far, the discussions in this area have been generally divided into two categories. One focuses on the causality relationship between international trade and economic growth to examine whether economic growth is propelled by international trade or vice versa. The other mainly discusses the contribution of foreign trade to economic growth.

The OECD (2003) conducted a study on the impact that trade had on the average income per population. According to the result, the elasticity of international trade was 0.2, which was statistically significant. Maizels (1963) discussed the positive relationship between international trade and economic development by a rank correlation analysis among 7 developed countries. Kavoussi (1984), after studying 73 middle and low-income developing countries, found out that higher rates of economic growth was strongly correlated with higher rates of export growth. He showed that the positive correlation between exports and growth holds for both middle- and low-income countries, but the effects tend to diminish according to the level of development. Balassa (1986) and Dollar (1992) argued that outward-oriented developing economies achieve indeed much more rapid growth than inward-oriented developing ones. Sachs and Warner (1995) constructed a policy index to analyze economic growth rate, and found that the average growth rate in the period after trade liberalization is significantly higher than that in the period before liberalization. Kraay (1999) investigated whether firms "learn" from exporting using a panel data of 2105 Chinese industrial enterprises between 1988 and 1992, and found the "learning” effects are most pronounced among established exporters. Keller (2001) discussed that international trade which involves importing intermediate goods of a high quality contributed to the diffusion of technology. Frankel and Romer (1999) constructed measures of the geographic component of countries' trade, and used those measures to obtain instrumental variables estimates of the effect of trade on income. The result 
showed that trade has a quantitatively large and robust positive effect on income even though it is only moderately significant statistically. Coe and Helpman (1995) studied the international R\&D diffusion among 21 OECD countries and Israel over the period of 1971-1990, and found that international trade is an important channel of transferring technology.

In sum, most empirical studies support the positive effects of openness on economic growth. From the comprehensive literature, both static and dynamic gains from trade could be found. The static gains from international trade refer to the improvement in output or social welfare with fixed amount of input or resource supply. They are mainly the results from the increase in foreign reserves and national welfare. Firstly, opening up to the global market offers an opportunity to trade at international prices rather than domestic prices. This opportunity provides a gain from exchange, as domestic consumers can buy cheaper imported goods and producers can export goods at higher foreign prices. Furthermore, there is a gain from specialization. The new prices established in free trade encourage industries to reallocate production from goods that the closed economy was producing at a relatively high cost (comparative disadvantage) to goods that it was producing at a relatively low cost (comparative advantage). By utilizing its comparative advantage in international trade, a country could increase the total output and social welfare.

Another long-term benefit of trade is the dynamic gain. This refers to the change in production structure thanks to the adoption of new technologies from abroad and an increase in the production scale. Firstly, international trade sectors based on comparative advantage always enjoy the economies of scale through the expansion in production stimulated by the massive demand from the global market. This results in the decrease of production costs, a large amount of accumulation of capital and increase in employment. Secondly, international trade is one of the channels supporting technological spillovers among countries which results in a favorable impact on the productivity level (Saggi, 2000). Endogenous growth of an open economy is achieved through "learning by doing" which exhibits diffusion of technology across goods and countries. International trade, which transmits knowledge internationally, could increase the absorptive capacity of trading countries by promoting technological advancement. Increased productivity is also achieved through practice and innovation. Finally, international trade leads to robust institutional changes. International trade not only facilitates trading of goods and services, but also ideas on market mechanisms. Developing countries are learning to apply market power more efficiently with less intervention from government to increase openness. Especially in bilateral and multilateral trade, participants should fulfill their commitments to international rules and regulations to bridge the gap between developed countries. 


\section{China's Trade}

\subsection{Evolution of China’s International Trade Policy}

Some of the unprecedented development in the Chinese trade sectors and trade policy also had various effects on the nation's economic growth. Targeting the global market, China has successfully converted itself from an inward-oriented country which was protected by various trade policies to an outward-oriented one with an open market. The transition from a closed economy to an open one accompanied with it various experiences. From the perspective of trade policy, China underwent a number of evolution periods, such as dependence on the Soviet Union, absolute isolation, and opening doors to the world. WTO accession, which represents a new milestone in China's trade evolution, enabled China to participate in the world trade under the global framework by improving the multilateral trade system.

Before 1978 ,China’s planned economic strategy and inward-oriented policy resulted in the subordinate status of international trade in the national economy. China had only minimal trade with the outside world, exporting just surplus raw materials and simple manufactured goods to cover payments for imported goods, including strategic minerals and other necessities not available in the domestic market.

The planned economy and import substitution policy optimized China's export structure by encouraging the growth of domestic industry during the initial period. A number of national industries were established to foster economic growth. However, due to lack of competition, the optimization of resource allocation could not be achieved, and the Chinese trade sectors could not enjoy the dynamic benefits from international trade such as competition effects, efficiency effects and technology improvement effects.

It is well known that China has pursued unparalleled trade liberalization since 1978. Since then, China has gained tremendous benefits from its integration into the global trade system. The political line and open-door economic strategy determined by the Third Plenary Session of the Party's 11th Central Committee initiated a new phase in China's economic relations with foreign countries. With the establishment of the socialist marketing economy and the transition of the Chinese economy and society, great changes have taken place in the country. China's opening has moved step by step from coastal cities to inland ones. Sustained development of the national economy and the increase of the average income present a great need for international trade which makes an increasingly significant contribution to economic growth.

From the perspective of the import regime, China was devoted to reducing trade barriers and enhancing its openness to the world. At the beginning of the 1980s, tariffs on many products were set to block the flood of foreign products into the Chinese market. The Chinese government canceled its import substitution list in the 1980s to 
encourage the market mechanism to achieve effective resource allocation with less intervention from the government. The initial tariff was set at the high rate of $56 \%$ in 1982. In the following two decades, China launched a massive tariff cut by at least ten times, reducing the average tariff rate to $15 \%$ in 2001 and $9.8 \%$ in 2008 . In the meantime, a broad array of non-tariff barriers such as licenses and quotas were reduced massively. The export quota was reduced from 227 (in 1992) to 66 (in 2001) and the import quota from 53 (in 1992) to 33 (in 2001) respectively ${ }^{1}$.

After easing many of the pervasive and various import and export restrictions in the 1980s, the value of imports exceeded that of exports as a result of fostering the domestic manufacturing industry by importing capital goods. A large part of these imports, which covered mainly energy, raw materials, machinery, electronics, light and textile industries, came from Japan, the United States and the former West Germany. During 1989-1992, the demand for imports fell below that for exports. The imports were mainly focused on energy, oil and petrochemicals. Thanks to the broad liberalization of the policies taken by Deng Xiaoping during the 1992 Southern China Trip, a great number of foreign investors set up joint ventures and imported leading technology to China. Foreign direct investment in China played an important role in capital accumulation, as well as in the transfer of management skills and technology.

In addition, China has made an all-out effort to raise the level of science and technology by implementing various international trade policies. The Ministry of Science and Technology of China and the former Ministry of Foreign Trade and Economic Cooperation of China proposed the strategy of "Trade Vitalization through Science and Technology” in 1999, which contributed to the increase of high-tech trade and the application of high technology to upgrade domestic industries. At this stage, the strategy of "Trade Vitalization through Science and Technology" increased in importance from a ministerial program to a national strategy gradually. Through the common efforts mad by the government and all sectors of society, the work of "Trade Vitalization through Science and Technology" made remarkable achievements. The government support for high-tech exports and the establishment of a favorable environment for high-tech industries enabled China to achieve rapid development of technology.

After 15 years of endeavor, China formally became the 143rd member of the World Trade Organization (WTO) at the 4th WTO Ministerial Meeting held in Doha, capital of Qatar on December 11, 2001. Entering the WTO was a strategic decision made by the Chinese government in the era of economic globalization. With its huge political influence, a giant economy and its status as a top global trader, China's accession to the WTO will help to strengthen and improve the multilateral trading system, promote world economic and trade development, and establish a new, open and just international economic order. Furthermore, WTO accession has largely contributed to reducing the technological gap between China and developed countries as it provided domestic

${ }^{1}$ Chinese Ministry of Commerce 
industries with increasing access to foreign equipments and leading technology.

To meet the requirements for joining the WTO, China started to modify and improve laws and administrative regulations, including those involving foreign trade and economic cooperation in 1999 (Cross, 2004). Laws and regulations not in compliance with WTO regulations were revised or nullified. By the end of 2001, China had revised 2,300 corresponding laws and regulations. In addition, China revised the Copyright Law, the Trademark Law, and the Law on Joint Ventures with Chinese and Foreign Investment in 2001.

After WTO accession, China has devoted much time and efforts to reducing trade barriers. On January 1, 2004, China lowered its average tariff rate by $0.6 \%$ to $10.4 \%$, and in 2008, the average tariff rate was below $10 \%$. In the meantime, China agreed to eliminate import quotas, licenses, designated trading practices and other non-tariff barriers. In addition, automobiles, chemicals and electronics industries which were subject to strong government protection before are likely to experience restructuring due to the dismantling of trade barriers (Greeven 2004).

Apart from its efforts to continuously reduce tariffs, China has also committed to an open trade in services market. The government opened up many service sectors where foreign participation was previously non-existent or marginal. These sectors include telecommunications, financial and insurance services. In those sectors, full access will eventually be guaranteed to foreign investors. China will also remove restrictions on trading and domestic distribution for most products (Rumbaugh and Blancher, 2004). The newly emerging industries, like telecommunication, banking, insurance, and professional services will be flooded with foreign competitors equipped with leading technology and management skills, and future opportunities for technology transfer exist in these industries.

China's accession to the WTO enables the country to enjoy the benefit of increased overseas market access. China is now permanently granted most-favored-nation (MFN) treatment by other WTO members, which is a significant step toward normalizing its trade relations (Rumbaugh and Blancher, 2004). Also, most other trading partners have eliminated restrictions on imports from China which helped promote China's labor-intensive exports in a large number of industries. China will also benefit from the settlement of future trade conflicts under the framework of the WTO. 


\subsection{China's Trade Performance}

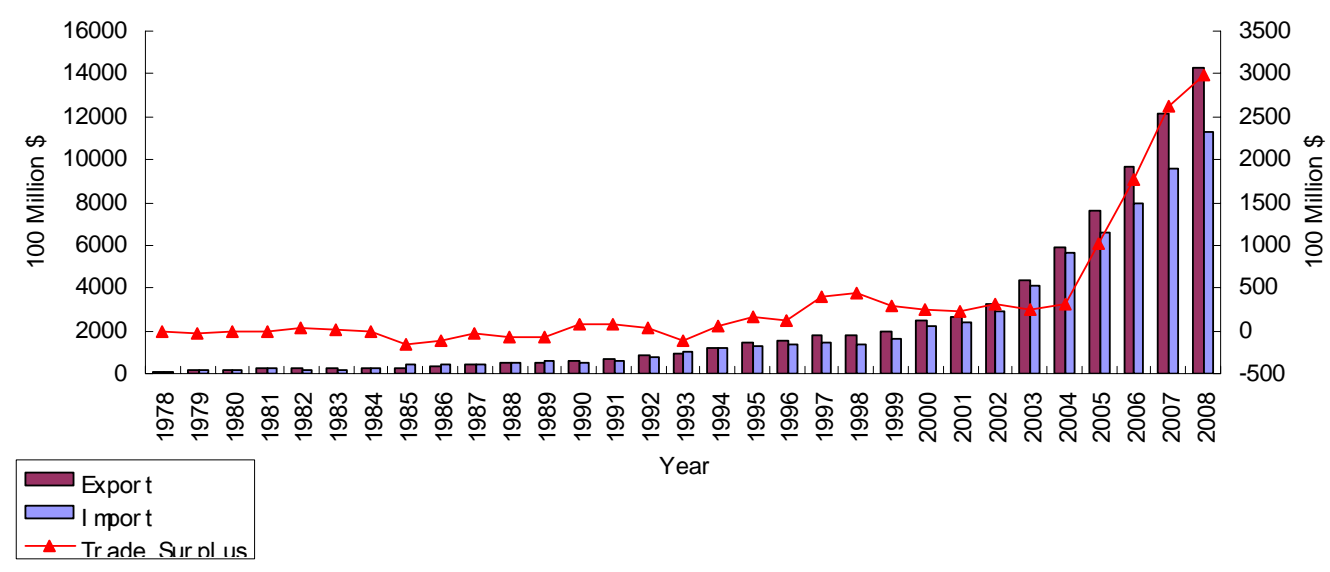

Figure 1. China trade statistics (1978-2008), Source: Chinese Ministry of Commerce

China's international trade has expanded steadily since the implementation of opening policy in 1978. It serves as a distinguishing case which highlights how a latecomer can carve out a place in the international trade market. As shown in Figure 1, China's international trade volume has grown fast in the last 20 years with an annual expansion rate of $18.1 \%$. It climbed from 20.64 billion dollars in 1978 to 2.56 trillion dollars in 2008, indicating the increasing opening-up of the Chinese economy. As for the trade balance, the total value of imports was comparable or sometimes even higher than the value of exports until the early 1990s.

As shown in Figure 2, China's share in global trade and its global ranking have increased steadily since 1979. In 2008, China took up 7.9\% in the global trade, and its global rank in terms of trade value was No. 3 (ranked after the U.S. and Germany).

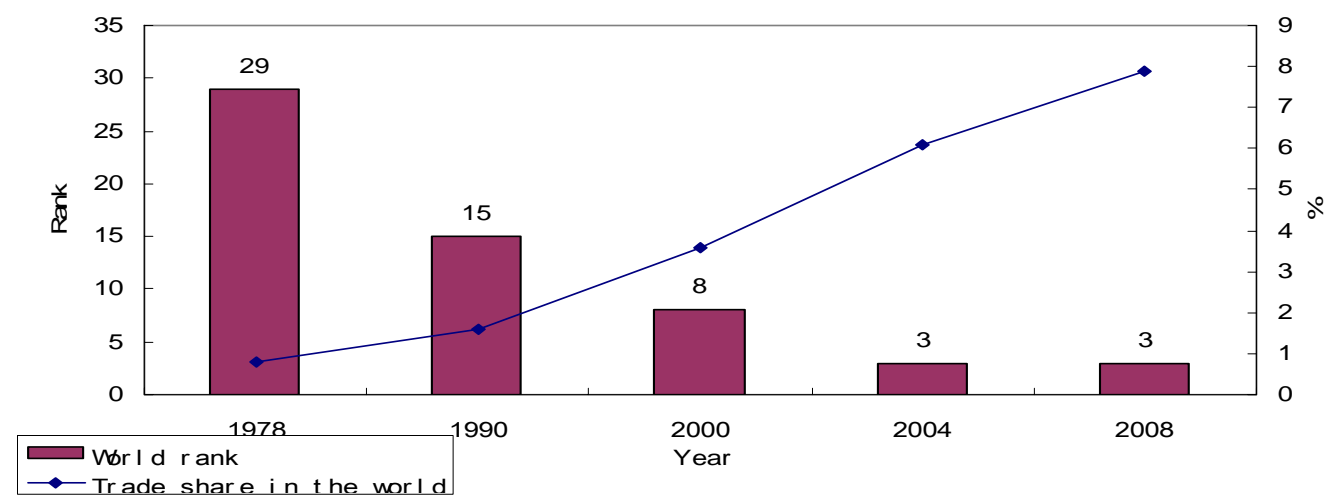

Figure 2. China trade rank and share in the world, Source: 60 Years of New China

China's overall trading structure has experienced obvious changes with the rapid growth of foreign trade volume (Lemoine and Ünal-Kesenci, 2004). Its rapid entry into the global market accelerated the early exit from labor-intensive exports. Structural 
reforms undertaken by China in recent years have significantly strengthened its global competitiveness and trade performance.

As for primary and manufactured goods, in 1980, primary goods accounted for $50.3 \%$ of total exports, while manufactured goods accounted for $49.7 \%$. In 2008, the share of primary goods was only $5.4 \%$, while manufactured goods expanded their share to a dominant level of $94.6 \%$ (Figure 3).

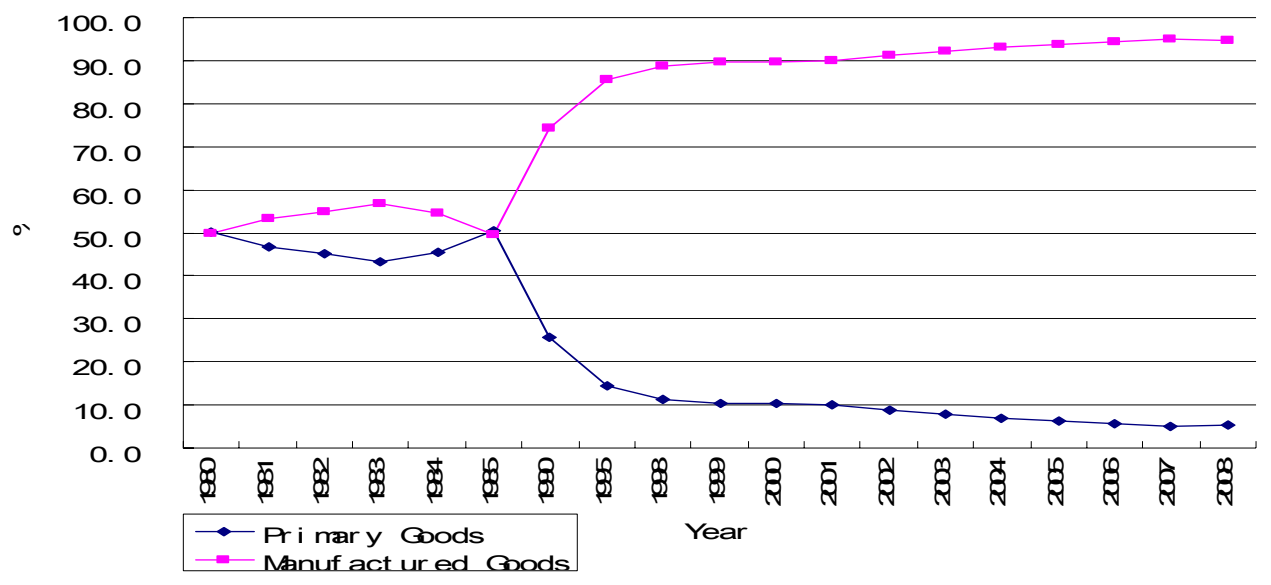

Figure 3. China’s export structure, Source: Chinese Statistical Yearbook

The above analysis suggests that one of the most remarkable aspects of China's trade performance was the rapid shift in the composition of exports from resource- and labor-intensive products to capital- and technology-intensive goods. China's trading structure changed its focus from primary products to light industry and textile products in the early 1990s, and to machinery and electronic goods with high technology now. Processing operations have contributed significantly to the improvement of China's manufactured exports with massive technology transfer through intermediate goods. It provides evidence that the technological upgrading of China's international trade has led to the building-up of highly internationalized and competitive industries including the electrical machinery sector.

Arora and Vamvakidis (2004) discussed the effects of trading partner on economic growth. They pointed out that industrial countries benefit from trading with developing countries which are growing at a rapid pace, while developing countries gain benefit from trading with developed countries which have a relatively high level of income and technology. Zhu (2007) analyzed China's trade with 26 OECD members and found that both intra-industry trade and inter-industry trade are critical in China's international trade patterns.

An analysis of the leading trade countries in 2008 indicated that the EU, the U.S. and Japan were the top 3 countries/regions in terms of their share in the global trade volume with $17.14 \%, 14.08 \%$ and $6.29 \%, 2$ respectively. The combined share of these 3

${ }^{2}$ WTO website, calculated by the author 
countries was $37.52 \%$, indicating the dominant position of these countries in the global trade. As for China, OECD members have also remained its major trading partners for a long time. The share of trade with the EU, the U.S. and Japan accounted for $40 \%$ of the total trade. And the share of relevant trade with top 10 OECD countries took up $75.9 \%$ in 2008. Table 1 shows the top 10 trading partners of China in 2008 in terms of trade volume and share. It could be concluded that the trading partners of China are generally the leading trade countries in the world.

Table 1. Top 10 trade partners of China in 2008

\begin{tabular}{lrr}
\hline Country & Trade volume (Billion \$) & Share (\%) \\
\hline \hline European Union & 425.58 & 16.60 \\
United Sates & 333.74 & 13.00 \\
Japan & 266.79 & 10.40 \\
ASEAN & 231.12 & 9.00 \\
Hong Kong, China & 203.67 & 8.00 \\
Korea & 186.11 & 7.30 \\
Taiwan, China & 129.22 & 5.00 \\
Australia & 59.66 & 2.30 \\
Russia & 56.83 & 2.20 \\
India & 51.78 & 2.00 \\
\hline
\end{tabular}

Source: Chinese Statistical Yearbook

China is a huge country which possesses one fifth of the world's population and has a vast territory of some 9.60 million square kilometers with 22 Provinces, 5 Municipalities, 4 Autonomous Regions and 3 Special Administrative Region. China's economy has experienced a sharp growth, reflecting special characteristics stemming from regional disparities, as well as its trade performance.

According to the Chinese government, China's provinces could be divided into 3 parts based on locations and economic development. The east region, which refers to the eastern coastal area, comprising 11 provinces such as ShangHai, GuangDong, JiangSu, etc., is endowed with a more developed infrastructure, technology and much more educated labor force thanks to favorable geographical conditions and historical reasons. These advantages help the eastern region attract more foreign direct investment, which results in active technology transfer and considerable economic growth. As compared with the eastern region, the central region, which includes 8 provinces neighboring the east one, and the western region, which covers 12 provinces in the interior western area, are less developed in terms of productivity and economic growth rate. Figure 4 shows that the GDP per capita varies among these three regions. Figure 5 describes the different trade volume per capita among them. The eastern region recorded the highest number in both GDP per capita and trade per capita, while the western region lags far behind with the lowest number in both of them. 


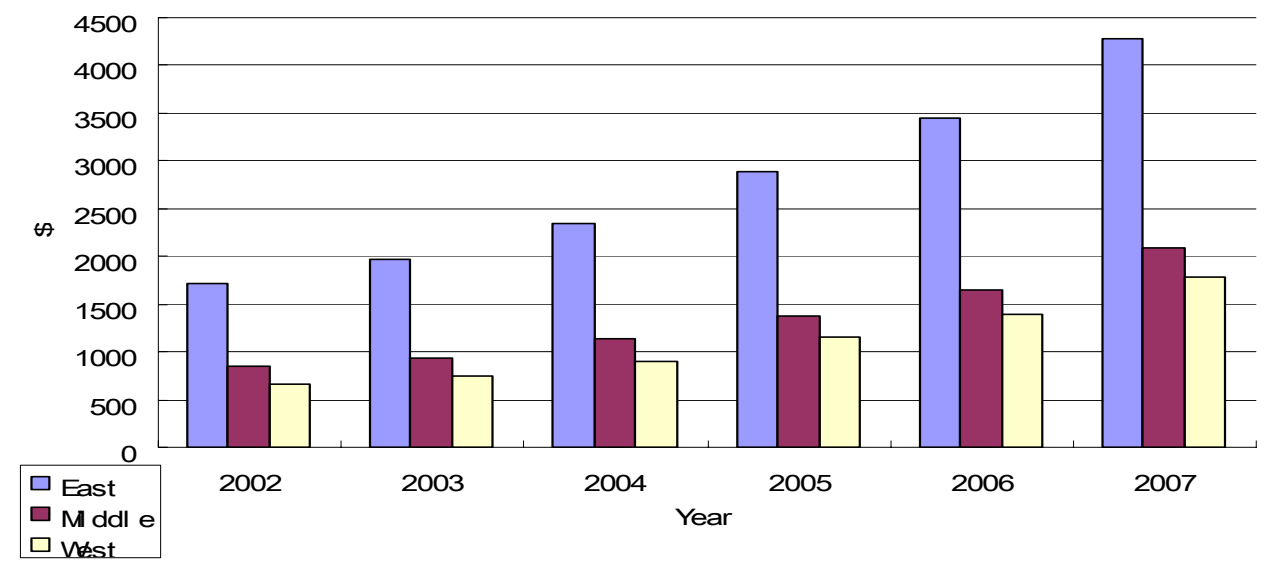

Figure 4. GDP per capita by region, Source: Chinese Statistical Yearbook, calculated by the author

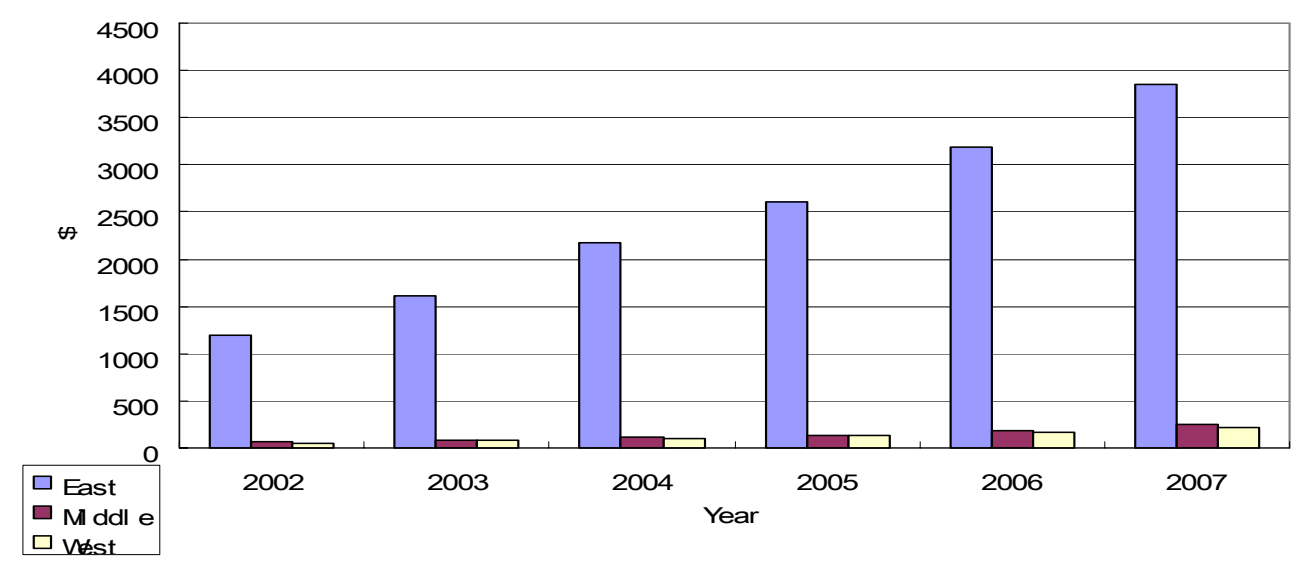

Figure5. Trade per capita by region, Source: Chinese Statistical Yearbook, calculated by the author

\section{Methodology and Estimation}

Based on the literature and previous research, there are both parametric and non-parametric methods in estimating technical efficiency or productivity of decision-making unit (DMU). The non-parametric method is developed by data envelopment analysis (DEA) which was proposed by Chames et al. (1978). It has been considered a method with strong advantages, employing linear programming, non-parametric approaches to measure the relative efficiency of decision-making units (DMUs) with the same goals and objectives, by using multiple inputs and outputs. The disadvantage of DEA is the lack of error estimation. Another non-parametric approach is using index numbers, which are the most commonly-used instruments to measure 
changes in levels of various economic variables (Coelli et al., 2005). To measure productivity changes, index numbers are used in measuring changes in the levels of outputs and inputs over time or across space. The parametric method is represented by stochastic frontier analysis (SFA). It allows estimating frontier production function by using quantitative analysis.

In this research, both econometric and non-parametric approaches are applied. For the econometric approach, a stochastic frontier production function at the provincial level in China is applied with two-stage estimation. Firstly, it involves the specification and estimation of the stochastic frontier production function and the prediction of the technical inefficiency effects with inputs, such as capital, labor and R\&D investment, under the assumption that these inefficiency effects are identically distributed. The second stage involves the specification of a regression model for the predicted technical inefficiency effects with the variables of characteristic, which include international trade factors, such as net export ratio and high-tech exports ratio. For the non-parametric approach, the Divisia index of each province is calculated as the benchmark compared to the econometric approach.

\subsection{Stochastic Frontier}

Since the stochastic frontier production function was proposed in Aigner et al. (1977), Meeusen and Broeck (1977), Battese and Corra (1977), there has been considerable research to extend and apply the model. Reviews of much of this research are provided in Fprsund et al. (1980), Schmidt (1986), Bauer (1990), and Battese (1992). According to Kumbhakar and Lovell (2000), these original SFA models shared the composed error structure, and each was developed in a production frontier context.

The stochastic frontier production function allows the existence of technical inefficiencies of production of DMUs. The possibility of obtaining producer-specific estimates of efficiency is one of the desirable advantages over other methods. However, most theoretical stochastic frontier production functions have not explicitly formulated a model for these technical inefficiency effects in terms of appropriate explanatory variables. Others including Pitt and Lee (1981), Kalirajan (1981), Huang and Liu (1994), Battese and Coelli (1995) proposed models for the technical inefficiency effects involved in stochastic frontier functions in order to explain these inefficiency effects. Not only for cross-section data, the determinant factors of the stochastic frontier and the inefficiency effect are estimated simultaneously for panel data, which could track the performance of each DMU through a sequence of time period. According to Coelli (1996), the general SFA model is described as follows:

$$
Y_{i t}=X_{i t} \beta+\left(V_{i t}-U_{i t}\right), \mathrm{i}=1,2, \ldots, \mathrm{N} ; \mathrm{t}=1,2, \ldots, \mathrm{N}
$$

where $Y_{i t}$ is (the logarithm of) the production of the $\mathrm{i}$-th firm in the t-th time period; $\mathrm{X}_{\mathrm{it}}$ is a $\mathrm{k} \times 1$ vector of (transformations of the) input quantities of the $\mathrm{i}$-th firm in the $\mathrm{t}$-th 
time period; $\beta$ is a vector of unknown parameter; $V_{\text {it }}$ are random variables which are assumed to be iid $N\left(0, \sigma_{v}^{2}\right)$, and independent of the $\mathrm{U}_{\mathrm{it}}$. $\mathrm{U}_{\mathrm{it}}$ are non-negative random variables which account for technical inefficiency in production and are assumed to be independently distributed as truncations at zero of the $N\left(U_{i t}, \sigma_{u}^{2}\right)$ distribution.

$$
T E_{i t}=\exp \left(-U_{i t}\right)
$$

Technical efficiency (TE) takes a value between zero and one. It measures the output of the i-th DMU relative to the output that could be produced by a fully-efficient DMU using the same input vector. When $\mathrm{U}_{\mathrm{it}}=0, \mathrm{TE}_{\mathrm{it}}=1$, indicating $\mathrm{DMU}$ is above frontier; when $\mathrm{U}_{\mathrm{it}}>0$, $\mathrm{TE}_{\mathrm{it}}<1$, showing $\mathrm{DMU}$ is below frontier.

Battese and Coelli (1995) assumed parameter $\gamma=\sigma_{u}^{2} /\left(\sigma_{v}^{2}+\sigma_{u}^{2}\right)$ to examine the proportion of technical inefficiency in the disturbance. $\gamma$ is between 0 and 1 . If $\gamma=0$, the distance between actual output and maximum output is only attributed to uncontrolled random factor. Therefore, the OSL method is much more adoptable than the SFA method.

In order to further explain the variation in technical efficiency among different DMUs, Battese and Coelli (1995) introduced technical inefficiency function as below:

$$
U_{i t}=\delta_{0}+Z_{i t} \delta+w_{i t}
$$

where $\delta_{0}$ is constant, $\delta$ is the coefficient of $\mathrm{z}_{\mathrm{it}}$, which is the determinant factor of technical inefficiency, $\mathrm{w}_{\mathrm{it}}$ is the random error. If $\delta>0$, it indicates a negative effect on technical efficiency and vise versa.

Cobb-Douglas and Translog function are two widely used functions in estimating stochastic frontier production function. The former is simple with the assumption of neutral technical change and constant return to scale, while the latter could catch the non-neutral technical change and scale augmenting effect.

\subsection{Index Numbers and Productivity Measurement}

Total factor productivity (TFP) could also be measured by the non-parametric approach as index numbers with advantages in being relatively easy to compute and analyze. These approaches do not need construction of econometric methods. TFP values are obtained by using only a few accounting based financial data. However, these approaches assume long-term equilibrium and constant returns to scale in modeling (Oh et al., 2008). Non-parametric methods regard productivity as residuals of growth of output, and thus not explicable in terms of growth of inputs. No sophisticated 
specification of the relationship, estimation, or distributional assumptions is required. According to Baltagi and Griffin (1988), TFP growth rate could be calculated as the difference in the percentage growth in output less the percentage change in a Divisia index of inputs as below:

$$
T F \dot{P}_{i t}=\dot{Y}_{i t}-\sum_{j} \varepsilon_{j} \dot{X}_{j i t}
$$

where $\dot{Y}_{i t}$ is the output growth rate of i observation in time t, $\varepsilon_{j}$ is the cost share or output elasticity of input $\mathrm{j}$ for i observation in time $\mathrm{t}$, and $\dot{X}_{i j t}$ is the input growth rate for i observation in time t. The growth rate is defined as:

$$
g X_{t}=\left(X_{t}-X_{t-1}\right) / X_{t-1}
$$

If it is the first year in dataset, the growth rate is fixed to be zero. Thus, the productivity level of each DMU for each year is measured relative to the previous one as shown in Function 6.

$$
T F P_{t}=T F P_{t-1}(1+\operatorname{TFP}), \quad T F P_{b a s e}=1
$$

\subsection{Testing Model Specification and Selection}

The likelihood ratio test is a method to test nested model assumptions. The likelihood ratio test compares the goodness of fit of the unrestricted with restricted models using the log likelihood function. In this research, the log-likelihood ratio test is applied to determine the best model which should be applied.

The procedure of log-likelihood ratio test can be stated as below (Ruud, 2000): (i) Compute the value of the log-likelihood function for the restricted model $\hat{\theta}$ which can be noted as $\log L_{\hat{\theta}}$, and note that the restricted model should be nested in the unrestricted model $\theta$; (ii) Compute the value of the log-likelihood function for the unrestricted model $\theta$ which can be noted as $\log L_{\theta}$; and (iii) Compute:

$$
{\log L R_{\hat{\theta}-\theta}}=-2\left(\log L_{\hat{\theta}}-\log L_{\theta}\right)
$$

(iv) Compare $\operatorname{LogLR}_{\hat{\theta}-\theta}$ with the critical value of a chi-square $\chi^{2}$ distribution with $K-M$ degrees of freedom, or restrictions, here $K$ is the number of parameters in unrestricted model, $M$ is the number of parameters in restricted model. If 


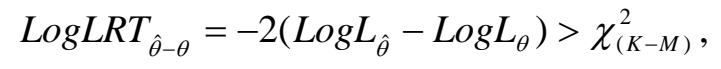

accept the unrestricted model $\theta$, otherwise accept the restricted model $\hat{\theta}$.

\subsection{Model Specification}

In this research, stochastic frontier analysis is used as the econometric approach to estimate the efficiency factors of China's 31 provinces during a 6-year period. Firstly, Cobb-Douglas production function is constructed to estimate the elasticity of input as below:

$$
\ln \left(G D P_{i t}\right)=\beta_{0}+\beta_{1} \ln \left(K_{i t}\right)+\beta_{2} \ln \left(L_{i t}\right)+\beta_{3} \ln \left(L R \& D_{i t}\right)+\beta_{4}(\text { Year })+V_{i t}-U_{i t},
$$

where output GDP ${ }_{i t}$ is a function of the logarithms of capital stock $\left(\mathrm{K}_{\mathrm{it}}\right)$, labor $\left(\mathrm{L}_{\mathrm{it}}\right)$ and lag $\mathrm{R} \& \mathrm{D}_{\mathrm{it}} \cdot \mathrm{V}_{\mathrm{it}}$ are random variables which are assumed to be iid $N\left(0, \sigma_{v}^{2}\right)$, and independent of the $U_{i t}$. $U_{i t}$ are non-negative random variables which account for technical inefficiency in production and are assumed to be independently distributed as truncations at zero of the $N\left(U_{i t}, \sigma_{u}^{2}\right)$ distribution.

In the second stage, technical inefficiency function is defined by Function 10:

$$
U_{i t}=\lambda_{0}+\lambda_{1}\left(N E X P R_{i t}\right)+\lambda_{2}\left(H T E X P R_{i t}\right)+\lambda_{3}\left(\text { TelR } R_{\mathrm{it}}\right)+\lambda_{4}(\text { East })+\lambda_{5}(\text { West })+\lambda_{6} \text { Year }+\omega_{i t}
$$

where inefficiency is a liner function of net export ratio, high tech export ratio, capacity of local office telephone exchanges per labor, two dummy location variables as west and east, and years. $\mathrm{w}_{\mathrm{it}}$ is the random error. The year variable in the inefficiency model (10) specifies that the inefficiency effects may change linearly with respect to time.

Additionally, technical efficiency (TE) of each province for a certain year is calculated by Function 11.

$$
T E_{i t}=\exp \left(-U_{i t}\right)
$$

For this econometric approach, the maximum-likelihood estimates of the parameters in the model are obtained by using a computer program, FRONTIER 41.

For the non-parametric approach, TFP of each province in certain time is calculated by using the Divisia index shown in equation 4. The growth rates in output, inputs (capital, labor and R\&D investment) and total factor productivity level of each province for each year is computed as in equation 5 and 6 . 


\section{Data and Variables}

\subsection{Input and Output of Production Function}

Regional Real GDP. The regional nominal GDP series and national CPI indices (Consumer Price Index) with comparable price to proceeding year are found in Chinese Statistics Yearbook 2002 to 2007. An implicit GDP deflator series could be calculated accordingly. The regional GDP was normalized to the base year (2002) level with measurement in 100 million Yuan. (Appendix 1 shows the CPI indices from 2002 to 2007 and the indices in the base year 2002)

Regional Capital Stock (K). In this research, regional capital stock is used to estimate the production function. The capital stock data is not available in the Chinese statistics. Only capital investment data is provided by the statistics office. So the capital stock might be a potential source for varying results produced by different authors at present. In this research, it is calculated based on the flows of capital investment according to perpetual inventory methods as shown below:

$$
K_{i, t}=I_{i, t}+(1-\delta) K_{i, t-1}
$$

where Kit, Iit are capital stock and capital investment of province i at year t, and $\delta$ is comprehensive depreciation rate of capital stock. According to Kuo and Yang (2008), to simplify the calculation, we could assume that the initial capital stock is very small in the infinite time span, and that investment grows at a constant annual growth rate of $\mathrm{g}$. Therefore:

$$
K_{i t}=I_{i t}+(1-\delta) I_{i t-1}+(1-\delta)^{2} I_{i t-2}+\ldots=\sum_{t}^{\infty} I_{i t}(1-\delta)^{t}=I_{i t} \sum_{t}^{\infty}\left[\frac{1-\delta}{1+g}\right]^{t} \approx I_{i t}\left(\frac{1+g}{g+\delta}\right)
$$

This research assumes that the depreciation rate is $7.5 \%$ and the growth rate of capital is 15\% according to Yao (2006). The capital stock of the base year (2002) for each province can be calculated by equation 13. And the capital stock of subsequent years could be calculated by the basic equation 12. All the capital stocks are deflated using PPI (Producer Price Index, as in Appendix 1) indices and measured in 100 million Yuan.

Labor $(\mathbf{L})$. In this research, regional employed person is used as another input variable in production function. This indicator reflects the actual utilization of total labor force during a certain period of time, and is often used for the research on China's economic status and national power. The provincial employed person is provided in Chinese Statistics Yearbook 2002 to 2007, measured in 10 thousand people. The 2006 data of provincial employed person is missing due to unclear reason. The national employed person in 2005 and 2006 are used to calculate the growth rate between 2005 and 2006. Then the provincial employed person in 2006 is estimated by the provincial employed 
person in 2005 multiplied by the national employed person growth rate.

Lag patent granted No. (LR\&D). According to endogenous growth theory promoted by Romer (1990), Grossman and Helpman (1991), long-term growth rate is due to endogenous factors including technological progress which comes from the activity of $\mathrm{R} \& \mathrm{D}$, invention, innovation, and so forth. Consequently, $R \& D$ investment is another important factor in production function. In this research, one-year lag patent granted number is used as the proxy variable for R\&D investment. In this research, the regional patent granted number from 2002 to 2007 is used as a proxy variable in production function indicating the $R \& D$ investment. The data is fully available in Chinese Statistics Yearbook 2002 to 2007. There is also a time lag between patent number and R\&D investment. This research assumes one year lag effect.

Year. Time effect is also studied in the production function by employing time trend from 2002 to 2007. The time variable in the stochastic production function accounts for Hicksian neutral technological change.

\subsection{Variables in the Inefficiency Function}

Theoretically, there are so many factors which could have an impact on efficiency. This research only examines the influence of the major factors relating to international trade, such as international trade volume and structure. Some other factors are also taken into consideration, such as information and communication technology (ICT) infrastructure and location effects.

Net export ratio (NEXPR). Previous research shows net export is one of the main contributor to economic growth. In this research, the net export ratio is used as a variable in inefficiency function. The provincial data of export and import could be found in Chinese Statistics Yearbook 2002 to 2007. Then the net export (the difference between export and import) is deflated by PPI and divided by the real GDP. This ratio shows the share of net export in GDP of every province in a certain period of time.

High-tech export ratio (HTEXPR). Trade structure also has an impact on efficiency. It is assumed that the change of focus in trade structure from labor-intensive goods to capital-intensive and high-tech goods leads to the rise in efficiency. China's export structure has transformed dramatically since the implementation of the "Open Door" policy. There has been a significant decline in the share of agriculture and soft manufacturing while the share of high-tech goods has been on the rise. Therefore, high-tech export ratio is used as another variable in inefficiency function. This ratio is provided in the website of China Science and Technology Statistic with the definition of high-tech exports divided by total exports.

Capacity of local office telephone exchanges per labor (TelR). It has been widely discussed that ICT makes a significant contribution to economic growth by improving productivity. China has become the largest country in terms of the number of telephone 
users since 2002. This is not only due to the large population size, but also thanks to the increasing ICT investment (Heshmati and Yang, 2006). In this research, investment in ICT is represented by local telephone exchanges divided by labor. The data could be found in Chinese Statistics Yearbook 2002 to 2007.

Dummy variables. A dummy variable (also known as binary variable or a zero-one variable) is one that takes the values 0 or 1 to indicate the absence or presence of some qualitative factors that may be expected to shift the outcome (Wooldrige, 2006). As discussed previously, due to the unbalanced development of China's economy, regions where a province is located have different effects on efficiency. The Chinese provinces could be divided into three parts based on locations and economic development (Appendix 2). The eastern region, referring to the eastern coastal area, comprises 11 provinces, such as GuangDong, JiangSu, etc. As compared with the eastern region, the central region, which includes 8 provinces neighboring the east one, and the western region, which covers 12 provinces in the interior western area, are less developed in terms of both productivity and economic growth rate. Therefore this research uses two dummy variables (East and West) to find out the location effect on inefficiency based on the central region. Moreover, this location effect could also be measured by using continuous variables, like the distance to the technology cluster or the most developed province/city. This distance indicates how separated one province/city is from the most developed one. According to the spillover theory, the distance to the technology cluster or the most developed province/city is negatively correlated to the economic development of this province/city.

Year. In contrast to the year variable in production function, the year variable in inefficiency model specifies that the inefficiency effects may change linearly with respect to time. The time trend is used covering years from 2002 to 2007.

\subsection{Data Description}

The basic data used in this research is a 6-year balanced panel data which consists of a sample of China's 31 provinces/regions observed from 2002 to 2007. The total number of observation is 186. The source of data is mainly from China Statistical Yearbook 2002 to 2007. The observations are grouped according to the location to investigate the geographical effect on efficiency. The regional GDP, capital stock and trade volume are normalized to the base year (2002) by CPI and PPI index.

Table 2 provides a brief descriptive statistics of the main variables used in this research. Appendix 3 and 4 show the summary of statistics by year and by region, respectively.

Table 2. Summary statistics of the variables, NT=186

\begin{tabular}{lrrrr}
\hline \multicolumn{1}{r}{ Variable } & Mean & Std.Dev & Minimum & Maximum \\
\hline \hline Real GDP & 5627.4859 & 5044.5931 & 161.4200 & 27300.5455 \\
Real Capital Stock & 12835.2472 & 11320.5589 & 557.1227 & 61484.7223
\end{tabular}




\begin{tabular}{lrrrr} 
Labor & 2178.5695 & 1499.6760 & 128.8000 & 5772.7000 \\
R\&D Lag & 4473.2096 & 6608.5437 & 7.0000 & 43516.0000 \\
Real IMP & 18397227.1400 & 38574626.8900 & 37448.8124 & 232573269.9000 \\
Real EXP & 21487408.7000 & 46481859.8400 & 81124.0000 & 324309117.4000 \\
Net EXP Ratio & 0.0089 & 0.1661 & -1.0339 & 0.3128 \\
High Tech EXP Ratio & 0.1073 & 0.1363 & 0.0000 & 0.7420 \\
Capacity of Local Office & 0.6894 & 0.3410 & 0.1891 & 2.0051 \\
Telephone Exchanges/labor & & & & \\
\hline
\end{tabular}

The description by year shows that, as time passed from 2002 to 2007, the level of real GDP as well as capital stock, labor and R\&D investment continuously grew. The mean value of GDP doubled in 6 years with an annual growth rate of 15\%. The rise in the mean value of capital stock is the most significant among input variables. Within 6 years, its mean value increased twofold with an annual growth rate of $38.9 \%$. Next, the R\&D input also increased by $134 \%$ in 6 years. The change in the mean value of labor is small with only $2.5 \%$ of annual growth rate. As for the trade volume, the mean values of both imports and exports jumped twofold, indicating China's increasing participation in international trade. The net export also soared during this period, and the mean value of net export ratio shows an upward trend except in 2003 and 2004. High-tech export ratio increased from the mean value of 0.09 in 2002 to 0.11 in 2007, suggesting the improvement in export structure. The mean value of local telephone exchange per labor increased to 0.811 in 2006, followed by a slight drop to 0.779 in 2007 .

The description by region shows a number of striking heterogeneities between the regions. Only 35\% of provinces (11) are classified as the east region, while their GDP accounts for $59 \%$ of the total GDP of China. The mean values of GDP and trade volume in the east region are higher than those in the central and western regions. This clearly indicates a serious imbalance in China's economic development. The mean value of real GDP in the east region is almost twice as much as that of the central region and 4 times as much as that of the western region. From the perspective of input variables, the mean values of real capital stock and patent number in the east region are higher than those of the central and western regions. On the contrary, the mean value of labor of the eastern region, which is indicated by the number of employed persons, is lower than that of the central region but higher than that of west. From the perspective of inefficiency factors, the mean value of net export ratio in the east region is negative, suggesting a large amount of imports in this region. As for high-tech export ratio and local office telephone exchange ratio, the mean value of the east region remains higher than the rest. 


\section{Analysis of Result}

Based on the model constructed before, the panel data of 186 observations was analyzed by a computer program, FRONTIER 41, with a maximum-likelihood estimating approach. Both production function and the technical inefficiency effects were estimated respectively (as shown in Table3).

Table 3. Maximum Likelihood estimation result, $n=186$ observations.

\begin{tabular}{|c|c|c|c|}
\hline Variables & Coefficient & Standard-Error & T-ratio \\
\hline Intercept1 & 5.41E-02 & 1.47E-01 & 3.68E-01 \\
\hline K & $6.58 \mathrm{E}-01^{* * *}$ & 3.47E-02 & $1.90 \mathrm{E}+01$ \\
\hline $\mathrm{L}$ & $2.70 \mathrm{E}-01^{* * *}$ & $2.08 \mathrm{E}-02$ & $1.30 \mathrm{E}+01$ \\
\hline LR\&D & $7.75 \mathrm{E}-02^{* * *}$ & 2.60E-02 & $2.99 \mathrm{E}+00$ \\
\hline Year & $-6.45 \mathrm{E}-03$ & 1.61E-02 & -3.99E-01 \\
\hline Intercept2 & $3.97 \mathrm{E}-01^{* * *}$ & $6.76 \mathrm{E}-02$ & $5.87 \mathrm{E}+00$ \\
\hline NEXPR & $-3.04 \mathrm{E}-01^{* * *}$ & $9.24 \mathrm{E}-02$ & $-3.29 \mathrm{E}+00$ \\
\hline HTEXPR & $-4.42 \mathrm{E}-01^{*}$ & 2.61E-01 & $-1.69 \mathrm{E}+00$ \\
\hline TelR & $-2.68 \mathrm{E}-01^{* * *}$ & $9.77 \mathrm{E}-02$ & $-2.74 \mathrm{E}+00$ \\
\hline East & 2.29E-02 & 4.77E-02 & 4.80E-01 \\
\hline West & $2.50 \mathrm{E}-01^{* * *}$ & 4.32E-02 & $5.79 \mathrm{E}+00$ \\
\hline Year & 2.81E-02 & 1.23E-02 & $1.20 \mathrm{E}+00$ \\
\hline$\sigma^{2}$ & $1.97 \mathrm{E}-02^{* * *}$ & 3.79E-03 & $5.20 \mathrm{E}+00$ \\
\hline$\gamma$ & $9.94 \mathrm{E}-01^{* * *}$ & 3.02E-02 & $3.29 \mathrm{E}+01$ \\
\hline log likelihood function=130.20739 & & & \\
\hline
\end{tabular}

$\sigma^{2}=\left(\sigma_{v}^{2}+\sigma_{u}^{2}\right) ; \gamma=\sigma_{u}^{2} /\left(\sigma_{v}^{2}+\sigma_{u}^{2}\right) \quad{ }^{*}$ represents significant at $10 \%$ level; ${ }^{* * *}$ represents significant at $1 \%$ level.

\subsection{Results from Production Function}

As shown in Table 3, the signs of the coefficients of the stochastic production function are as expected, with the exception of negative sign of the year variable. The input of capital, labor and R\&D investment are positively related to output (GDP) with high significance. The year has a negative effect on production function, meaning the total value of output was on a downward trend at a small but insignificant rate over the 6 years. The elasticity of output with respect to each of the input $\varepsilon_{j}$ is directly interpreted by the coefficient of capital, labor and $R \& D$. The elasticity of output with respect to capital is relatively high at 0.66 , indicating high capital-intensity in production. This contrasts with the elasticity of labor and R\&D that are estimated at 0.27 and 0.08 , respectively. Since the T-statistic based on the estimated elasticity and standard error is more than 2, the hypothesis of zero input elasticity is rejected for all inputs.

Returns to scale are the measurement of the changes in the level of output resulting 
from proportional changes in input. Based on the result, returns to scale is calculated by the sum of elasticity. It stands at 1.01, indicating the increasing return to scale. This is consistent with the previous research result on China's provincial production conducted by Shiu and Heshmati (2006) and Feng (2007).

\subsection{Results of Efficiency}

As shown in Appendix 5, the efficiency of each DMU is calculated by FRONTIER 41 according to Function 11. Table 4 and 5 provide a breakdown of the samples' efficiencies into various categories (year and region). Figure 6 shows the regional efficiency trend in the 6-year period.

Table4. Summary of efficiencies by year

\begin{tabular}{lrrrrr}
\hline Year & Obs. & Mean & Std.Dev & Minimum & Maximum \\
\hline \hline TTL & 186 & 0.70523 & 0.14663 & 0.41385 & 0.99514 \\
2002 & 31 & 0.70979 & 0.70979 & 0.70979 & 0.70979 \\
2003 & 31 & 0.71316 & 0.15253 & 0.4299 & 0.98772 \\
2004 & 31 & 0.69347 & 0.14608 & 0.41385 & 0.98256 \\
2005 & 31 & 0.71899 & 0.14816 & 0.46155 & 0.99044 \\
2006 & 31 & 0.71685 & 0.14566 & 0.46391 & 0.99514 \\
2007 & 31 & 0.67909 & 0.13577 & 0.44946 & 0.96718 \\
\hline
\end{tabular}

Table 5. Summary of efficiencies by region

\begin{tabular}{lrrrrr}
\hline Region & Obs. & Mean & Std.Dev & Minimum & Maximum \\
\hline \hline East & 66 & 0.82614 & 0.10283 & 0.59514 & 0.99514 \\
Middle & 48 & 0.73765 & 0.09268 & 0.57504 & 0.98772 \\
West & 72 & 0.57277 & 0.09252 & 0.41385 & 0.85825 \\
\hline
\end{tabular}

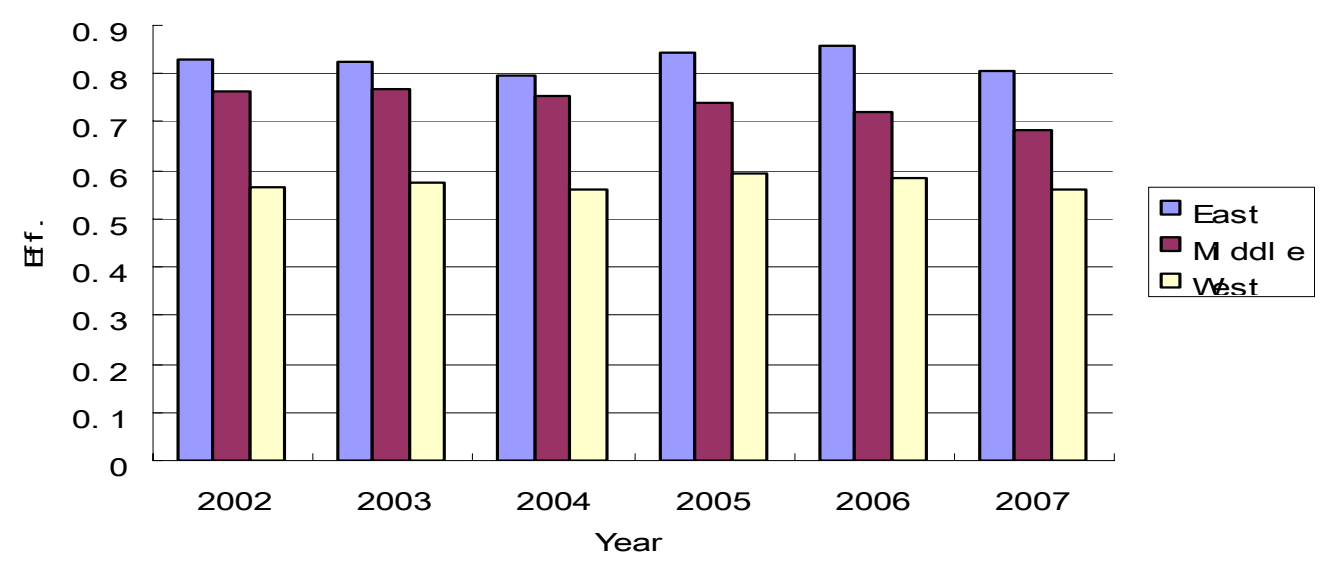

Figure 6. Regional efficiency from 2002 to 2007 
The mean value of efficiency shows a fluctuating trend from 2002 to 2007. It rises from 0.70 in 2002 to 0.71 in 2003 and then slightly drops to 0.69 in 2004. In 2005, after reaching the peak at 0.718 , the mean value of efficiency gradually decreases. The growth rate of efficiency between 2004 and 2005 is the highest at around 3.68\%.

From the perspective of regional specification, an obvious gap in the mean value of efficiency among different regions is shown in Figure 6. The mean efficiency of the eastern region is higher than that of the central and western regions as shown in Table 5. This also supports the hypothesis of the unbalanced development in China.

Table 6. Efficiency frequency distribution by year

\begin{tabular}{lrrrrrrrrrrrrr}
\hline Efficiency & \multicolumn{2}{c}{2002} & \multicolumn{2}{c}{2003} & \multicolumn{2}{c}{2004} & \multicolumn{2}{c}{2005} & \multicolumn{2}{c}{2006} & \multicolumn{2}{c}{2007} \\
interval & F. & \% & F. & $\%$ & F. & $\%$ & F. & $\%$ & F. & $\%$ & F. & $\%$ \\
\hline \hline $0.4-0.5$ & 3 & 9.68 & 3 & 9.68 & 2 & 6.45 & 3 & 9.68 & 3 & 9.68 & 3 & 9.68 \\
$0.5-0.6$ & 5 & 16.13 & 5 & 16.13 & 7 & 22.58 & 5 & 16.13 & 4 & 12.90 & 7 & 22.58 \\
$0.6-0.7$ & 7 & 22.58 & 7 & 22.58 & 8 & 25.81 & 7 & 22.58 & 8 & 25.81 & 6 & 19.35 \\
$0.7-0.8$ & 7 & 22.58 & 6 & 19.35 & 6 & 19.35 & 7 & 22.58 & 8 & 25.81 & 8 & 25.81 \\
$0.8-0.9$ & 4 & 12.90 & 5 & 16.13 & 5 & 16.13 & 5 & 16.13 & 5 & 16.13 & 4 & 12.90 \\
$0.9-1.0$ & 5 & 16.13 & 5 & 16.13 & 3 & 9.68 & 4 & 12.90 & 3 & 9.68 & 3 & 9.68 \\
\hline
\end{tabular}

Table 6 shows the efficiency frequency distribution by year. The proportion of provinces with the efficiency over 0.9 is the highest in 2002 at $16.13 \%$, and declines continuously to $9.68 \%$ in 2007 . This indicates the production becomes more inefficient over time. Most of the provinces recorded the efficiency level of around 0.6 to 0.8 . The big difference in efficiency frequency distribution could also be seen in Table 7. The largest proportion of efficiency level for the east region is $34.85 \%$ in level $0.8-0.9$; $43.75 \%$ in level $0.7-0.8$ for the middle, and $40.28 \%$ in level $0.5-0.6$ for the west.

Table 7. Efficiency frequency distribution by region

\begin{tabular}{lrrrrrr}
\hline \multirow{2}{*}{ Efficiency interval } & \multicolumn{2}{c}{ East } & \multicolumn{2}{c}{ Middle } & \multicolumn{2}{c}{ West } \\
& Freq. & $\%$ & Freq. & $\%$ & Freq. & $\%$ \\
\hline \hline $0.4-0.5$ & 0 & 0.00 & 0 & 0.00 & 17 & 23.61 \\
$0.5-0.6$ & 1 & 1.52 & 3 & 6.25 & 29 & 40.28 \\
$0.6-0.7$ & 8 & 12.12 & 16 & 33.33 & 19 & 26.39 \\
$0.7-0.8$ & 15 & 22.73 & 21 & 43.75 & 6 & 8.33 \\
$0.8-0.9$ & 23 & 34.85 & 4 & 8.33 & 1 & 1.39 \\
$0.9-1.0$ & 19 & 28.79 & 4 & 8.33 & 0 & 0.00 \\
\hline
\end{tabular}

To test whether the difference of efficiency among 3 regions in China is significant or not, one-way ANOVA test is applied in this research by SPSS. In statistics, analysis of variance (ANOVA) is a collection of statistical models and their associated procedures, in which the observed variance is partitioned into components due to different 
explanatory variables. In its simplest form, ANOVA offers a statistical test of whether the means of several groups are all equal, and therefore generalizes two-sample t-test to more than two groups. Table 8 shows the result of the ANOVA test by SPSS. The highly significant F-value indicates a huge difference in efficiency level exists among 3 regions.

Table 8. One-way ANOVA test result

\begin{tabular}{lrrrrr}
\hline Variance & Sum of Squares & df & $\begin{array}{r}\text { Mean } \\
\text { Square }\end{array}$ & F & Significance. \\
\hline \hline Between Groups & 2.279 & 2 & 1.139 & 122.723 & 0.000 \\
Within Groups & 1.699 & 183 & 0.009 & & \\
Total & 3.977 & 185 & & & \\
\hline
\end{tabular}

\subsection{Results from Inefficiency Function}

The estimated coefficients in the inefficiency model, which are listed in Table 3, are of great significance in this research. According to the study on the signs of each inefficiency factors, the coefficients of net export per GDP, high-tech export ratio, capacity of local office telephone exchanges per labor show the negative effect on inefficiency. However, the dummy variables of the East, West and Year demonstrate a negative effect on inefficiency. From the perspective of significant level, the coefficients of net export per GDP, capacity of local office telephone exchanges per labor and dummy variable of the West are significant at the $1 \%$ level, while that of high-tech export ratio is significant at almost $10 \%$ level. However, the coefficients of the East and Year are not significant at all.

The estimation for the variance parameter $\gamma$ is significant at the $1 \%$ level, indicating that technical inefficiency is the main reason for less desirable production that is below the frontier production. And it is very close to 1 , which shows that the inefficiency effects are likely to be highly significant in the analysis.

Table 9. Likelihood-ratio test results

\begin{tabular}{lccccc}
\hline Null Hypothesis & $\mathrm{H}_{1}$ (Likelihood) & Ho(Likelihood) & $\chi_{0.95}^{2}$ & $\begin{array}{c}\text { Test } \\
\text { Statistic }\end{array}$ & Result \\
\hline \hline Ho: $\gamma=\lambda_{1}=\lambda_{2}=. .=\lambda_{6}=0$ & 130.207 & 75.345 & 14.07 & 109.724 & Rejected Ho \\
Ho: $\lambda_{1}=\lambda_{2}=. .=\lambda_{6}=0$ & 130.207 & 82.09 & 12.59 & 96.234 & Rejected Ho \\
\hline
\end{tabular}

The results of generalized likelihood-ratio test of null hypotheses are listed in Table 9. The first null hypothesis, which specifies that inefficiency effects are absent from the model, is objected strongly. The second null hypothesis specifies that the inefficiency effects are not a linear function of the inefficiency factors selected in this research, such 
as net export ratio and high-tech export ratio. This null hypothesis is also rejected at $5 \%$ level of significance. This signifies that the joint effects of the total 6 explanatory variables on the inefficiencies are significant even though some of the individual effects are less significant statistically. Thus, it appears that the inefficiency stochastic frontier production function proposed in this research is a significant improvement over the corresponding model which does not include the technical inefficiency effects.

\subsection{Results from Non-parametric Approach}

As for the non-parametric approach, Table 10 and 11 demonstrate the difference in total factor productivity (TFP) over time and across regions by calculating the Divisia index. The TFP exhibits a decreasing trend except in 2005. In 2007, the TFP records the lowest number at 0.89 . From the regional perspective, the western region recorded the highest number of TFP while the middle region recorded the lowest.

It seems contrary to the efficiency number derived from the econometric approach. The reason is that the TFP in the base year (2002) is set to be 1 regardless of the regional effect. And the decreasing rate of TFP in the eastern region is more dramatic than that of the western region. Actually, the TFP in the base year should be different among regions.

Table 10. Summary of TFP by year

\begin{tabular}{lrrrrr}
\hline Year & Obs. & Mean & Std.Dev & Minimum & Maximum \\
\hline \hline TTL & 186 & 0.963 & 0.1096 & 0.6761 & 1.3441 \\
2002 & 31 & 1.000 & 0.0000 & 1.0000 & 1.0000 \\
2003 & 31 & 0.994 & 0.0418 & 0.9203 & 1.1371 \\
2004 & 31 & 0.946 & 0.0583 & 0.8271 & 1.1192 \\
2005 & 31 & 0.983 & 0.1389 & 0.7818 & 1.3422 \\
2006 & 31 & 0.963 & 0.1376 & 0.7566 & 1.3441 \\
2007 & 31 & 0.890 & 0.1485 & 0.6761 & 1.2563 \\
\hline
\end{tabular}

Table 11. Summary of TFP by region

\begin{tabular}{lrrrrr}
\hline Region & Obs. & Mean & Std.Dev & Minimum & Maximum \\
\hline \hline East & 66 & 0.963 & 0.0140 & 0.6931 & 1.3441 \\
Middle & 48 & 0.935 & 0.1158 & 0.6761 & 1.2893 \\
West & 72 & 0.980 & 0.0985 & 0.7103 & 1.2346 \\
\hline
\end{tabular}




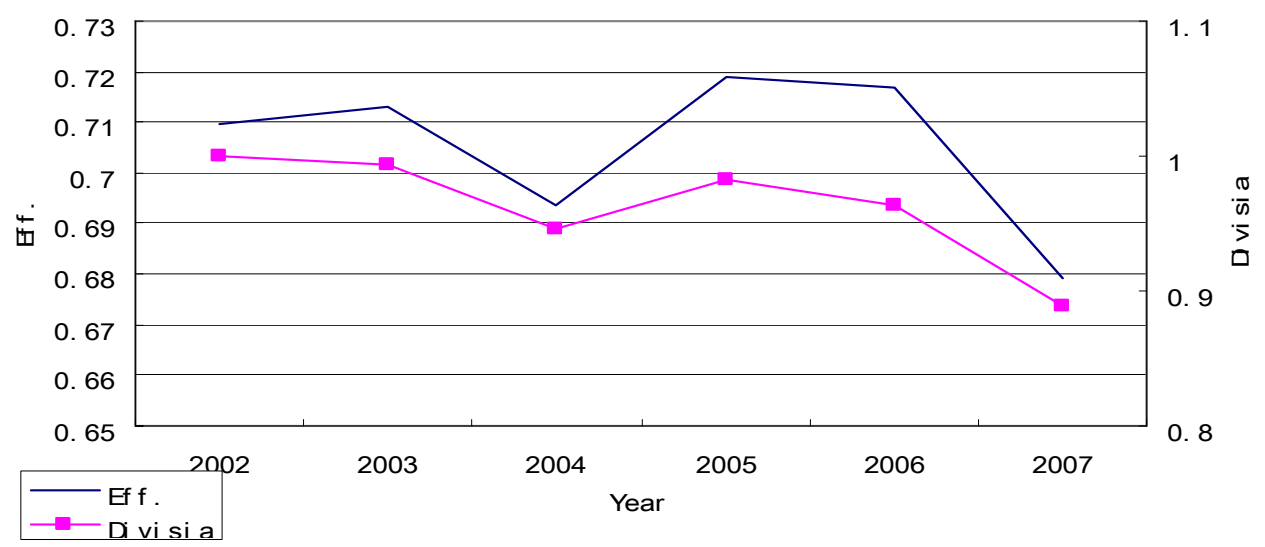

Figure 7. Comparison of Efficiency with the Divisia Index

The comparison of both efficiency measurement and non-parametric approach is shown in Figure 7. Obviously, both of them show similar trends. A big drop in 2004 and a dramatic rise in 2005 are reflected by results from both approaches. This justifies the robustness of both econometric approach and non-parametric approach.

\subsection{Discussion on the Results}

The net export share in GDP shows a significant positive effect on efficiency. It means that the higher the net export ratio of one province, the more efficient the production of this province is. This is consistent with the literature and the hypothesis in this research. Adequate evidence in the trade history of China could be found to prove that exports played an important role in industrialization. Before 1992, the static benefits of international trade, which led to expansion in employment and accumulation of a great amount of foreign reserves, were brought in. After that, China implemented an outward-oriented strategy and intensified efforts to pursue free market reform, which brought about more dynamic benefits of international trade, such as the improvement in the TFP through learning by doing and accumulation of human capital. In addition, the productivity of China's processing sectors which used a large amount of imported parts and components as resource was enhanced significantly because of the accessibility to technology-intensive intermediate goods. Consequently, China's specialization in processing industries led to the improvement of domestic technological capability. Thanks to the advancement of technology, management and organization innovation, China's export enterprises improved productivity to a large extent, which generated the spillover effects across sectors.

High-tech export ratio also has a positive effect on the efficiency level but is less significant. This is a little inconsistent with the hypothesis that the improvement in trade structure by focusing the shift from labor-intensive products to high-tech intensive products could have a significantly positive correlation with the efficiency. It shows 
that China's exports are now more technologically advanced than expected given its level of development. High-tech exports, one of the main drivers of economic growth, increasingly contribute to China's international trade. However, there are still several problems in the high-tech trade sectors. Firstly, since the imported high-tech parts and components are used in export processing industries, China's exports are confined to processing by low-cost labor. Due to the lack of independent intellectual property and core technological know-how, the high value-added high-tech products exported by China are attributed to its abundance in low-cost labor. Secondly, imbalance in high-tech exports results in heavy reliance on the international market. Exports of information and communication technology (ICT) products accounts for over $90 \%$ of the total high-tech exports. However, other high-tech exports such as aerospace, biotechnology and materials goods only account for a minimal share. Consequently, the fluctuating demand from the global market could be a potential threat to the high-tech export sectors. Finally, the geographically unbalanced development in high-tech exports widens the gap between the developed eastern region and underdeveloped middle and west regions. This also explains why the high-tech export ratio is positively correlated to the efficiency but the effect is less significant.

The capacity of local office telephone exchanges per capita demonstrates a significant positive effect on the efficiency. Since the 1990s, the convergence of the IT industry and the communications industry has been the driving force of the global economy. A telephone exchange is a system of electronic components connecting telephone calls. This indicator represents the investment in ICT across provinces. The positive effect signifies that the ICT capacity leads to the improvement of efficiency by reducing the transportation and transaction costs. In addition to the investment in ICT sectors, however, China, still a developing country, should also devote time and efforts to increase the efficiency of complementary factors, such as infrastructure, human capital and education that make the ICT sector more productive.

The dummy variable of the East shows a negative effect on efficiency but with less significance. However, the West demonstrates a significant negative effect on efficiency. This supports the previous research on the unbalanced development across China. The provinces located in the eastern region have experienced the most rapid growth. The east region, referring to the eastern coastal area comprising 11 provinces such as ShangHai, GuangDong, JiangSu, etc., is endowed with a more developed infrastructure, technology and much higher levels of labor force thanks to favorable geographical conditions and historical reasons. These advantages help the eastern region attract more foreign direct investment, resulting in technology transfer and considerable economic growth. However, after China's accession to the WTO, the advantages enjoyed by the east region are diminishing gradually due to the excessive investment and severe competition. The increase in cost of labor, land and public resources such as electricity, water and gasoline, eliminates the comparative advantage of the eastern part of China gradually. So the location effect of the east on the efficiency is not significant at all. The western provinces are still lagging behind. Some provinces in the west of China, such 
as Qinghai and Gansu, fall behind others due to poor resource endowment and the lack of infrastructure and human resources, and environmental problems. These disadvantages result in the less participation in the global trade and inefficient use of input to generate output. Inter-provincial trade can have a relatively stronger effect on economic growth than the international trade. To close this gap, the Chinese government has launched the policy of "Grand Western Development Strategy" since 2000. Under this strategy, the Chinese government has exerted their all-out efforts to steer state investment, expertise, capital, FDI and international trade into the west- the less developed region - with a favorable policy. As international trade has a positive effect on GDP growth, the western and central provinces should endeavor to achieve a higher level of openness to reap the direct and indirect benefits from trade as mentioned above.

Finally, the dummy variable Year had negative effects on efficiency but less significant, which indicates technical deterioration over time.

From the perspective of the change in efficiency and TFP level, there was an obvious drop in 2004 which could be attributed to the epidemic bird flu, resulting in a significant shrinking of the trade sector and the Chinese economy. The continuous downward trend in efficiency and the TFP level is attributable to the excessive investment and competition in China, especially in export sectors. This led to the misallocation of resourced and inefficient use of input.

\section{Policy Implication}

In light of this research, the conclusion that foreign trade exerts great positive effects upon China's economic growth could be drawn. China, however, is facing some serious problems such as low domestic absorptive capability, deterioration of the terms of trade, the negative impact of trade on the environment, trade friction with partners and uneven development across the country. All of them may impose negative impacts on the sustainable development of China's foreign trade. Therefore, to achieve sustained economic growth, China should pay more attention to the proper and appropriate trade strategies and policies.

Firstly, China should develop strategies to promote exports and high-tech trade. This study showed that the rise in net export volume and improvement in trade structure towards high-tech products could increase the efficiency of provincial production. A large amount of exports imply greater openness which could help domestic sectors adopt new production technology and in turn increase productivity. During the last decades, the abundant labor supply contributed to the rapid economic development in China dramatically. Trade liberalization has enabled China to achieve a high degree of specialization in the sectors in which it has a comparative advantage, e.g. labor-intensive industries. The exports of labor-intensive goods such as textiles helped 
China take part in the global specialization and import enough capital goods to pursue domestic industrialization. The accelerated expansion in labor intensive industries also helped the Chinese government contain the rise of unemployment which has become the most serious problem of China's economy since the end of the 1990s. However, the development model, narrowly focusing on the comparative advantage, could result in the deterioration of the terms of trade and limited technology transfer. Learning-based productivity growth could be better achieved by encouraging the development of technologically sophisticated products which could transfer more technology to domestic sectors. Therefore, the Chinese government should exert great efforts to help export sectors improve the trade structure towards high-tech goods. The production and exports of high-pollution, high-energy-consumption, low-value-added, and labor-intensive goods should be reduced gradually. And the government should support high-tech trade by closely cooperating with FDI partners in capital-intensive and high-tech intensive industries.

Secondly, the Chinese government should strengthen the competitiveness of export sectors by combining the imports of foreign high-technology and domestic independent research. The technological know-how could be imported by direct buying or indirect FDI. However, the domestic absorptive ability in China is very weak. Therefore, on one hand, the Chinese government should try to import appropriate technology which can easily be absorbed and acquired by domestic firms with their corresponding capability. On the other hand, it is important to develop strong domestic sector of competitive firms that can assimilate and disseminate imported technologies and to improve their own innovative capacities. Because most of export products lack independent intellectual property, the ability to assimilate and disseminate should be enhanced to a large extent by integrating an innovation system into the international trade sectors. Moreover, China should focus on the catch-up strategy by establishing a national innovation system which includes proper education, finance and industry policy. By promoting openness and enhancing domestic absorptive capability, the competitiveness of the Chinese products could be increased enormously.

Thirdly, policymakers should take notice of the unbalanced development pattern in the provincial area. To close the gap between the east and the west regions, the Chinese government has adopted the policy of "Grand Western Development Strategy" since 2000. Under this strategy, the Chinese government has exerted their full efforts to steer state investment, expertise, capital, FDI and international trade into the less developed western region with favorable policy. In the future, on one hand, the Chinese government should provide support to the western and central regions, which are lagging behind both in economic development and trade performance, and help them achieve a higher level of openness for efficient development. Due to the increase in the cost of labor and public resources in most of the eastern provinces, the middle and western regions could take over the labor-intensive industry from the eastern region and join the vertical specialization for the first time. The eastern region could concentrate on the development of capital and high-tech intensive industries and horizontal 
specialization by taking advantage of the accessibility to foreign direct investment and the established infrastructure. On the other hand, in order to create more opportunities for the middle and western regions to participate in international trade, investment in building-up of infrastructure and human capital should also be taken into consideration by the government. The development of infrastructure including transport, hydropower plants, energy, and telecommunications should be supported by the central and regional government. And R\&D investment also plays an important role in promoting the absorptive capability of the less developed regions. The education and R\&D investment in the middle and western regions could also help them better utilize the productive resources and adopt technology transferred from FDI. And the western and middle regions should also try to restrain the outflow of human resources to richer regions by providing incentives such as high wages or subsidies. By eliminating regional disparity in access to education and wages, the problem of the regional gap in China will be addressed gradually.

Finally, China should take an active part in the global trade rulemaking process and in solving trade frictions. The multilateral trade rules of GATT/WTO have weakened the role of government administration and intervention in trade. The government providing support to domestic industries should know at which point their protection should be withdrawn. However, the rules of global trade play an increasingly imperative role in resolving trade frictions between countries. Especially since China joined the WTO, most enterprises have directly entered the international market, and more frequently, they have applied all kinds of international trade laws. Hence, the decision, still under consideration by the Chinese authorities, to take the initiative to formulate and fulfill the international trade rules would be another step towards leveling the playing field of global standardization.

\section{Summary and Conclusion}

This in-depth research has applied both qualitative and quantitative approaches to discuss the relationship between international trade and China's economic growth. Based on the comprehensive literature, it reviewed the evolution of China's trade regime as well as trade policy. This was followed by the use of both econometric and non-parametric methods to estimate China's provincial efficiency and to examine the major determinant factors in terms of participation in international trade. For the econometric approach, stochastic frontier production function was applied to evaluate the effects of international trade on China's economic growth. This was done by analyzing the improvement in productivity based on a 6-year panel data covering 31 provinces of China. The likelihood ratio test indicated that the inefficiency effects were significant, reaffirming the suitability of the stochastic frontier model. Meanwhile, for the non-parametric approach, the Divisia index of each province was calculated as the benchmark compared to the econometric approach. 
The empirical results showed the increasing returns to scale in the provincial production function in China during 2002-2007, with the input of capital, labor and investment of R\&D investment. As to efficiency factors, net export ratio, high-tech export ratio and capacity of local office telephone exchanges per labor had positive effects on efficiency. This indicates the rise in net export volume and improvement in trade structure towards high-tech products could increase the efficiency of provincial production. The analysis of the distribution and level of efficiency and the Divisia index suggested that the east region in China has experienced the most rapid growth, while the central and west provinces have been lagging behind in terms of both productivity and international trade, which indicates a seriously unbalanced development.

In sum, from this research, it is concluded that China's outstanding performance in economic growth can be traced back to its increasing involvement in global trade and dynamic trade policy. China's rapid economic growth has made the country target the world as its market. The increasing participation in the global market helps China reap the static and dynamic benefits from trade, facilitating the rapid national economic growth. The static benefits from international trade result from importing capital goods which embody high technology. And the dynamic effects of trade refer to the improvement in the TFP through learning by doing and accumulation of human capital. In addition, the productivity of China's processing sectors is enhanced significantly because of the accessibility to technology-intensive intermediate goods. Consequently, China's specialization in processing industries has driven the improvement of domestic technological capability. However, there are still some problems that China is facing now, such as the lack of independent intellectual property, low domestic absorptive capability and unbalanced development pattern.

Due to limitation on data collection, data used in this research only covers a period of six years. To analyze the relationship between international trade and economic growth, it would be better to cover a longer period of time. Indeed, since the implementation of opening policy in the 1980s, international trade volume and structure have changed significantly. Therefore, without the data before 2002, some of the more obvious changes might have been ignored, which may have influenced the result of the empirical analysis.

Moreover, there are many other ways to evaluate the international trade effect on economic growth such as the gravity model approach and causality model approach. These models could be applied in the further research on China's international trade. To evaluate the efficiency scores of each province in China, the data envelopment analysis is also a good alternative with the advantage of requiring no specific function when determining the production frontier. It could always be a benchmark to parametric models in further studies. 


\section{References}

Aigner D.J., C.A.K. Lovell and P. Schmidt (1977), Formulation and estimation of stochastic frontier production function models, Journal of Econometrics, 6(1), 21-37.

Arora V. and A. Vamvakidis (2004), How much do trading partners matter for economic growth?, IMF Working Paper, 04/26, Washington: International Monetary Fund.

Balassa B. (1986), Policy responses to exogenous shocks in developing countries, American Economic Review, 1986(5), 75-78.

Baltagi B.H. and J.M. Griffin (1988), A general index of technical change, The Journal of Political Economy, 96(1), 20-41.

Battese G.E. (1992), Frontier production functions and technical efficiencies: A survey of empirical applications in agricultural economies, Agricultural Economics, 7(3-4), 185-208.

Battese G.E. and T.J. Coelli (1995), A model for technical inefficiency effects in a stochastic frontier production function for panel data, Empirical Economics, 20(2), 325-332.

Battese G.E., and G.S. Corra (1977), Estimation of a production frontier model with application to the Pastoral zone of eastern Australia, Australian Journal of Agricultural Economics, 21(3), 169-179.

Bauer P.W. (1990), Recent developments in the econometric estimation of frontiers, Journal of Econometrics, 46(1-2), 39-56.

Chames A., W.W. Coope, and E. Rhodes (1978), Measuring the efficiency of decision making units, European Journal of Operational Research, 3(4), 339.

Coe D.T. and E. Helpman (1995), International R\&D spillovers, NBER Working Paper, No. 4444.

Coelli T.J. (1996), A guide to FRONTIER Version 4.1: a computer program for stochastic frontier production and cost function estimation, CEPA Working Paper, 96/07, Center for Efficiency and Productivity Analysis, University of New England.

Coelli T.J., D.S. Prasada Rao, C.J. O’Donnell and G.E. Battese (2005), An Introduction to Efficiency and Productivity Analysis, Second Edition, Springer Science+Business Media, LLC.

Cross, K.H. (2004), China's WTO accession: economic, legal, and political implications, Boston College International and Comparative Law Review, 27(2), 319-370.

Dollar D. (1992), Outward-oriented developing economies really do grow more rapidly: Evidence from 95 LDCs, 1976-1985, Economic Development and Cultural Change, 1992 (40) 523-544.

Feng Y. (2007), Productivity growth in Chinese economy and industries, Recent Development in the Chinese Economy, NOVA Science Publishers, Inc., 83-134.

Frankel J.A. and D. Romer (1999), Does trade cause growth?, American Economic Review, 89(3), 379-399. 
Fфrsund F.R., C.A.K. Lovell and P. Schmidt (1980), A survey of frontier production functions and their relationship to efficiency measurement, Journal of Econometrics, 13(1), 5-25.

Greeven M.J. (2004), The evolution of high-tech in China after 1978: Towards technological entrepreneurship, ERIM Report Series Research in Management, ERS-2004-092-ORG.

Grossman G.M. and E. Helpman (1991), Innovation and Growth in the Global Economy, MIT Press, Cambridge, Massachusetts.

Heshmati A. and W.S. Yang (2006), Contribution of ICT to the Chinese economic growth, RATIO Working Paper, No. 91.

Huang C.J. and J.T. Liu (1994), Estimation of a non-neutral stochastic frontier production function, Journal of Productivity Analysis, 5(2), 171-180.

Kalirajan K. (1981), An econometric analysis of yield variability in paddy production, Canadian Journal of Agricultural Economics, 29, 283-294.

Kavoussi R.M. (1984), Export expansion and economic growth, Development Economics, 14(1), 241-250.

Keller W. (2001), Knowledge spillovers at the world technology frontier, NBER Working Paper, 8150, 2001.

Kraay A. (1999), Exports and economic performance: Evidence from a panel of Chinese enterprises, Revue d'Economique du Developpement, 1999 (1-2),183-207.

Kumbhakar S.C. and C.A.K. Lovell (2000), Stochastic Frontier Analysis, New York, Cambridge University Press.

Kuo C.C. and C.H. Yang (2008), Knowledge capital and spillover on regional economic growth: Evidence from China, China Economic Review, 19(4), 594-604.

Lee J.W. (1995), Capital goods import and long-run growth, Development Economics, 48(1), 91-110.

Lemoine F. and D. Ünal-Kesenci. (2004), Assembly trade and technology transfer: The case of China, World Development, 32(5), 829-850.

Maizels A. (1963), Industrial growth and World Trade, Cambridge University Press.

Meeusen W. and J.V. Broeck (1977), Efficiency estimation from Cobb-Douglas production functions with composed error, International Economic Review, 18(2), 435-444.

OECD (2003), The Source of Economic Growth in OECD Countries, Paris: Organization for economic cooperation and development, 2003.

Oh I.H., J.D. Lee and A. Heshmati (2008), Total factor productivity in Korean manufacturing industries, Global Economic Review, 37 (1), 23-50.

Parikh A. and C. Stirbu (2004), Relationship between trade liberalization, economic growth and trade balance: An econometric investigation, HWWA Discussion Paper, 2004-282.

Pitt M.M. and M.F. Lee (1981), The measurement and sources of technical inefficiency in the Indonesian weaving industry, Journal of Development Economics, 9(1), 43-64. 
Romer P.M. (1990), Endogenous Technical Change. Journal of Political Economy, 98(5), 71-102.

Rumbaugh T. and N. Blancher (2004), China: international trade and WTO accession, IMF Working Paper, 04/36 March, Washington: International Monetary Fund.

Ruud P.A. (2000), An Introduction to Classical Econometric Theory, Oxford University Press, Inc., New York.

Sachs J.D. and A. Warner. (1995), Economic reform and process of global integration, Brookings Papers on Economic Activity, 26(1), 1-118.

Saggi K. (2000), Trade, foreign direct investment, and international technology transfer: A survey, World Bank Policy Research Working Papers, No. 2349.

Schmidt P. (1986), Frontier production functions, Econometric Reviews, 4(2), 289-328.

Shiu A. and A. Heshmati (2006), Technical change and total factor productivity growth for Chinese provinces: A panel data analysis, IZA Discussion Paper, No. 2133.

Wagner J. (2007), Exports and productivity: A survey of the evidence from firm level data, The World Economy, 30(1), 60-82.

Wang J.Y. (2007), The evolution of China's international trade policy: development through protection and liberalization, Economic Development Through World Trade, 191-213.

Yao S. (2006), On economic growth, FDI and exports in China, Applied Economics, 38(3), 339-351.

Zhu Z.G. (2007), A gravity model of China's trade flows, Recent Developments in the Chinese Economy, NOVA Science Publishers, Inc., 135-172. 


\section{Appendix}

Appendix 1. CPI and PPI

\begin{tabular}{lrrrr}
\hline Year & CPI & $\begin{array}{r}\text { CPI (2002 as } \\
\text { Base Year) }\end{array}$ & PPI & $\begin{array}{r}\text { PPI (2002 as } \\
\text { Base Year) }\end{array}$ \\
\hline \hline 2007 & 104.80 & 113.86 & 103.90 & 115.64 \\
2006 & 101.50 & 108.65 & 101.50 & 111.29 \\
2005 & 101.80 & 107.04 & 101.60 & 109.65 \\
2004 & 103.90 & 105.15 & 105.60 & 107.92 \\
2003 & 101.20 & 101.20 & 102.20 & 102.20 \\
2002 & 99.20 & 100.00 & 100.20 & 100.00 \\
\hline
\end{tabular}

Appendix 2. China regional division

\begin{tabular}{ccc}
\hline East & Middle & West \\
\hline \hline Beijing & Shanxi ${ }^{1}$ & Guangxi \\
Tianjin & Jilin & Guizhou \\
Hebei & Heilongjiang & Yunnan \\
Liaoning & Anhui & Shanxi $^{2}$ \\
Shanghai & Jiangxi & Gansu \\
Jiangsu & Henan & Qinghai \\
Zhejiang & Hubei & Ningxia \\
Fujian & Hunan & Xinjiang \\
Shandong & & Inner Mongolia \\
Guangdong & & Sichuan \\
Hainan & & Chongqing \\
& & Tibet \\
\hline
\end{tabular}

Note: 1:Capital is Taiyuan $\quad$ 2:Capital is Xi'an 
Appendix 3. Summary of statistics of variables by year, NT=186

\begin{tabular}{|c|c|c|c|c|c|c|c|c|c|c|c|c|c|c|}
\hline \multirow{2}{*}{ Year } & \multicolumn{4}{|c|}{ Real GDP } & \multicolumn{4}{|c|}{ Real Capital Stock } & \multicolumn{2}{|c|}{ Labor } & \multicolumn{4}{|c|}{ R\&D Lag } \\
\hline & \multicolumn{2}{|c|}{ Mean } & \multicolumn{2}{|c|}{ Std.Dev } & \multicolumn{2}{|r|}{ Mean } & \multicolumn{2}{|c|}{ Std.Dev } & Mean & Std.Dev & \multicolumn{2}{|c|}{ Mean } & \multicolumn{2}{|c|}{ Std.Dev } \\
\hline 2002 & \multicolumn{2}{|c|}{3807.12} & \multicolumn{2}{|c|}{3075.02} & \multicolumn{2}{|c|}{7088.01} & \multicolumn{2}{|c|}{5332.27} & 2074.72 & 1431.09 & \multicolumn{2}{|c|}{2868.45} & \multicolumn{2}{|c|}{3588.44} \\
\hline 2003 & \multicolumn{2}{|c|}{4320.39} & \multicolumn{2}{|c|}{3546.05} & \multicolumn{2}{|c|}{8537.05} & \multicolumn{2}{|c|}{6518.33} & 2124.61 & 1485.86 & \multicolumn{2}{|c|}{3249.29} & \multicolumn{2}{|c|}{4458.64} \\
\hline 2004 & \multicolumn{2}{|c|}{5008.07} & \multicolumn{2}{|c|}{4150.80} & \multicolumn{2}{|c|}{10796.51} & \multicolumn{2}{|c|}{8328.00} & 2139.00 & 1481.61 & \multicolumn{2}{|c|}{4409.03} & \multicolumn{2}{|c|}{6165.51} \\
\hline 2005 & \multicolumn{2}{|c|}{5960.27} & & 2.95 & 132 & 82.07 & & 94.20 & 2194.44 & 1532.31 & 4477 & & & .05 \\
\hline 2006 & 680 & 0.26 & & 1.10 & 164 & 16.79 & & 91.18 & 2204.75 & 1539.51 & 5101 & & & 64 \\
\hline 2007 & 780 & 8.82 & & 78.51 & 208 & 91.06 & & 31.05 & 2333.89 & 1630.44 & 6734 & & & .77 \\
\hline Year & Real & IMP & & & Real & EXP & & Net EX & P Ratio & $\begin{array}{r}\text { High } \mathrm{T} \\
\mathrm{R}\end{array}$ & $\begin{array}{l}\text { ch EXP } \\
\text { io }\end{array}$ & $\begin{array}{r}\mathrm{Ca} \\
\mathrm{Of} \\
\text { Exc }\end{array}$ & fice & $\begin{array}{l}\text { focal } \\
\text { lephone } \\
\text { per labor }\end{array}$ \\
\hline & Mean & & & & , & Std. & & Mean & Std.Dev & Mean & Std.Dev & $\mathrm{Me}$ & & Std.Dev \\
\hline 2002 & 9522680 & 2054 & & 1050 & 097 & 2254 & & 0.0005 & 0.1402 & 0.0919 & 0.1125 & 0. & & 0.2374 \\
\hline 2003 & 13159393 & 2716 & & 1397 & 15 & 29502 & & -0.0047 & 0.1588 & 0.0979 & 0.1263 & $0.5 \mathrm{~s}$ & & 0.4109 \\
\hline 2004 & 17223937 & 3458 & & 1820 & 000 & 36986 & & -0.0110 & 0.2026 & 0.1033 & 0.1370 & 0.68 & & 0.2953 \\
\hline 2005 & 19893738 & 3981 & & 2296 & 74 & 4614 & & 0.0143 & 0.1568 & 0.1260 & 0.1756 & 0.7 & & 0.3320 \\
\hline 2006 & 23503995 & 4695 & & 2877 & 980 & 57919 & & 0.0244 & 0.1739 & 0.1113 & 0.1349 & 0.81 & & 0.3392 \\
\hline 2007 & 27079621 & 5302 & & 3450 & 986 & 68310 & & 0.0302 & 0.1675 & 0.1132 & 0.1317 & 0.77 & & 0.3216 \\
\hline
\end{tabular}

Appendix 4. Summary of statistics of variables by region, NT=186

\begin{tabular}{|c|c|c|c|c|c|c|c|c|c|c|c|c|c|}
\hline \multirow{2}{*}{ Region } & \multicolumn{4}{|c|}{ Real GDP } & \multicolumn{4}{|c|}{ Real Capital Stock } & \multicolumn{2}{|r|}{ Labor } & \multicolumn{2}{|r|}{ R\&D Lag } & \\
\hline & \multicolumn{2}{|c|}{ Mean } & \multicolumn{2}{|c|}{ Std.Dev } & \multicolumn{2}{|r|}{ Mean } & \multicolumn{2}{|c|}{ Std.Dev } & Mean & Std.Dev & Mean & Std.Dev & \\
\hline East & \multicolumn{2}{|c|}{9359.99} & \multicolumn{2}{|c|}{6279.28} & \multicolumn{2}{|c|}{20615.5} & \multicolumn{2}{|c|}{14379.8} & 2401.92 & 1633.08 & 9510.41 & \multicolumn{2}{|l|}{8990.88} \\
\hline Middle & \multicolumn{2}{|c|}{5208.37} & \multicolumn{2}{|c|}{2303.56} & \multicolumn{2}{|c|}{11225.9} & \multicolumn{2}{|c|}{5676.59} & 2711.61 & 1406.28 & 2343.29 & \multicolumn{2}{|l|}{1185.04} \\
\hline West & \multicolumn{2}{|c|}{2485.43} & \multicolumn{2}{|c|}{1901.89} & \multicolumn{2}{|c|}{6776.22} & \multicolumn{2}{|c|}{5295.18} & 1618.48 & 1246.13 & 1275.72 & \multicolumn{2}{|l|}{1356.38} \\
\hline \multirow[t]{2}{*}{ Region } & \multicolumn{4}{|c|}{ Real IMP } & \multicolumn{3}{|c|}{ Real EXP } & \multicolumn{2}{|c|}{ Net EXP Ratio } & \multicolumn{2}{|c|}{$\begin{array}{r}\text { High Tech EXP } \\
\text { Ratio }\end{array}$} & \multicolumn{2}{|c|}{$\begin{array}{r}\text { Capacity of Local } \\
\text { Office Telephone } \\
\text { Exchanges per labor }\end{array}$} \\
\hline & Mean & & & & & Std.I & & Mean & Std.Dev & Mean & Std.Dev & Mean & Std.Dev \\
\hline East & 48199038 & 532 & & 5559 & & 65652 & & -0.0085 & 0.2759 & 0.2241 & 0.1626 & 0.9587 & 0.3641 \\
\hline Middle & 2864920 & & & 3818 & & 2055 & & 0.0118 & 0.0286 & 0.0426 & 0.0357 & 0.5607 & 0.2236 \\
\hline West & 1433772 & 12 & & 200 & & 1873 & & 0.0231 & 0.0349 & 0.0433 & 0.0606 & 0.5283 & 0.2087 \\
\hline
\end{tabular}


Appendix 5. Efficiency results, NT=186 observations.

\begin{tabular}{|c|c|c|c|c|c|c|c|c|}
\hline Region & Province/Year & 2002 & 2003 & 2004 & 2005 & 2006 & 2007 & Mean \\
\hline \multirow{11}{*}{ East } & Beijing & 0.63 & 0.62 & 0.60 & 0.84 & 0.848 & 0.81 & 0.72 \\
\hline & Tianjin & 0.89 & 0.93 & 0.91 & 0.99 & 0.995 & 0.94 & 0.94 \\
\hline & Hebei & 0.79 & 0.80 & 0.82 & 0.82 & 0.799 & 0.75 & 0.80 \\
\hline & Liaoning & 0.94 & 0.90 & 0.82 & 0.79 & 0.848 & 0.75 & 0.84 \\
\hline & Shanghai & 0.95 & 0.95 & 0.89 & 0.98 & 0.985 & 0.97 & 0.95 \\
\hline & Jiangsu & 0.90 & 0.89 & 0.87 & 0.87 & 0.863 & 0.80 & 0.87 \\
\hline & Zhejiang & 0.68 & 0.65 & 0.67 & 0.69 & 0.701 & 0.66 & 0.68 \\
\hline & Fujian & 0.98 & 0.96 & 0.90 & 0.85 & 0.873 & 0.80 & 0.90 \\
\hline & Shandong & 0.82 & 0.82 & 0.81 & 0.80 & 0.797 & 0.74 & 0.80 \\
\hline & Guangdong & 0.83 & 0.83 & 0.79 & 0.94 & 0.957 & 0.92 & 0.88 \\
\hline & Hainan & 0.73 & 0.74 & 0.69 & 0.71 & 0.759 & 0.72 & 0.72 \\
\hline \multirow{8}{*}{ Middle } & Shanxi & 0.60 & 0.69 & 0.69 & 0.79 & 0.731 & 0.71 & 0.70 \\
\hline & Jilin & 0.74 & 0.75 & 0.73 & 0.75 & 0.738 & 0.70 & 0.74 \\
\hline & Heilongjiang & 0.98 & 0.99 & 0.98 & 0.90 & 0.882 & 0.81 & 0.92 \\
\hline & Anhui & 0.74 & 0.72 & 0.71 & 0.67 & 0.628 & 0.58 & 0.67 \\
\hline & Jiangxi & 0.69 & 0.68 & 0.67 & 0.63 & 0.658 & 0.60 & 0.65 \\
\hline & Henan & 0.78 & 0.78 & 0.79 & 0.79 & 0.767 & 0.70 & 0.77 \\
\hline & Hubei & 0.83 & 0.80 & 0.77 & 0.70 & 0.682 & 0.69 & 0.75 \\
\hline & Hunan & 0.74 & 0.70 & 0.69 & 0.69 & 0.689 & 0.66 & 0.69 \\
\hline \multirow{12}{*}{ West } & Guangxi & 0.71 & 0.70 & 0.69 & 0.71 & 0.713 & 0.64 & 0.69 \\
\hline & Guizhou & 0.42 & 0.43 & 0.42 & 0.46 & 0.464 & 0.45 & 0.44 \\
\hline & Yunnan & 0.62 & 0.61 & 0.6 & 0.60 & 0.585 & 0.55 & 0.59 \\
\hline & Shanxi & 0.55 & 0.56 & 0.56 & 0.61 & 0.642 & 0.61 & 0.59 \\
\hline & Gansu & 0.54 & 0.55 & 0.55 & 0.59 & 0.616 & 0.59 & 0.57 \\
\hline & Qinghai & 0.48 & 0.50 & 0.50 & 0.53 & 0.557 & 0.56 & 0.52 \\
\hline & Ningxia & 0.43 & 0.43 & 0.41 & 0.48 & 0.507 & 0.52 & 0.46 \\
\hline & Xinjiang & 0.65 & 0.68 & 0.66 & 0.68 & 0.695 & 0.66 & 0.67 \\
\hline & Inner Mongolia & 0.69 & 0.73 & 0.70 & 0.86 & 0.684 & 0.71 & 0.73 \\
\hline & Sichuan & 0.60 & 0.60 & 0.59 & 0.58 & 0.583 & 0.56 & 0.59 \\
\hline & Chongqing & 0.57 & 0.55 & 0.52 & 0.50 & 0.487 & 0.45 & 0.51 \\
\hline & Tibet & 0.51 & 0.56 & 0.50 & 0.51 & 0.489 & 0.45 & 0.50 \\
\hline Mean & & 0.71 & 0.71 & 0.69 & 0.72 & 0.717 & 0.68 & 0.71 \\
\hline
\end{tabular}

